\title{
Fragilaria and Staurosira (Bacillariophyceae) from sediment surfaces of 40 lakes in the Austrian Alps in relation to environmental variables, and their potential for palaeoclimatology
}

\author{
Roland SCHMIDT*, Christian KAMENIK, Horst LANGE-BERTALOT ${ }^{1)}$ and Rolf KLEE ${ }^{2)}$ \\ Institute of Limnology, Austrian Academy of Sciences, Mondseestraße 9, A-5310 Mondsee, Austria \\ 1) J.W. Goethe-University, Botanical Institute, Siesmayerstraße 70, D-60323 Frankfurt a. M., Germany \\ ${ }^{2)}$ Bavarian Water Management Agency, Dep. of Aquatic Ecology Research, Demollstraße 31, D-82407 Wielenbach, Germany \\ *e-mail corresponding author: roland.schmidt@oeaw.ac.at
}

\begin{abstract}
The percentage distributions of Fragilaria and Staurosira taxa in surface sediment samples from 40 oligo- to ultra-oligotrophic, pH neutral to alkaline, mountain lakes of the central Austrian Alps (Niedere Tauern) were studied in relation to environmental variables using multivariate statistics. Selected taxa that were of uncertain taxonomy or that might be difficult to distinguish were illustrated in LM or SEM. The same statistics as they were applied to the total diatom data set were run on a Fragilariaceae subset with Fragilaria and Staurosira. These analyses emphasized on the high sensitivity of these genera to climate-driven environmental variables in mountain lakes. Canonical Correspondence Analyses (CCA) indicated that the pH, mean July water temperature ( $\left.T_{J u l y}\right)$, length of ice cover, and dissolved organic carbon (DOC) made significant contributions to explain the variation in the diatom assemblages. In addition, water depth affected the distribution of benthic and planktonic taxa. Differences or similarities in ecological preferences of taxa provided suggestions for taxonomy. Correlations between the mean valve length and summer water temperatures increase the overall high potential of Fragilaria and Staurosira for palaeoclimatological reconstructions in mountain lakes.
\end{abstract}

Key words: Diatoms, Fragilariaceae, Alpine lakes, Canonical Correspondence Analyses, $p H$, water temperature relations, ice cover, DOC

\section{INTRODUCTION}

Diatom species within the genera of Fragilaria and Staurosira are frequent in Alpine (e.g. Hustedt 1943; Lotter et al. 1999; Lotter \& Bigler 2000; Schmidt et al. 2001), arctic and subarctic lakes (e.g. Foged 1974; Smol 1988; Pienitz et al. 1995; Douglas \& Smol 1995; Weckström et al. 1997a, b; Laing et al. 1999), and under comparable environmental conditions in the past (e.g. Haworth 1975, 1976; Marciniak 1986, 1988). Alpine lakes are characterized by prolonged ice over, short growing seasons, low or moderate water temperatures, rapid changes in the chemical-physical properties during the melt period, low nutrients, clear-water phases with high light penetration, and intense UV radiation (Wögrath \& Psenner 1995; Sommaruga-Wögrath et al. 1999; Catalan et al. 2002).

The overall goal of this study was to evaluate the potential of Fragilariaceae for palaeoclimate reconstructions in Alpine lakes. Fragilariaceae are characterized by a high variability in shape, size, and microstructure (e.g. Williams \& Round 1987; Krammer \& Lange-Bertalot 1991). The following steps were performed: (1) We have split taxa with morphological variability into morphotypes. (2) Selected taxa that might be difficult to distinguish or of uncertain taxonomy were illustrated in the light microscope (LM) or were studied in the electron microscope (SEM). (3) We analyzed the chemical and physical variables in 40 lakes of the cen- tral Austrian Alps. (4) This environmental data set was used to explain changes in the total diatom assemblages and within a Fragilariaceae subset. (5) We also examined the effect of water temperature on valve length of selected taxa.

\section{STUDY SITES}

The 40 oligo- to ultra-oligotrophic lakes are located in the Niedere (Schladminger) Tauern, Eastern Central Alps (47 $\left.13^{\prime} 15^{\prime \prime N}-47^{\circ} 21^{\prime} 31^{\prime \prime N}, 13^{\circ} 36^{\prime} 06^{\prime \prime E}-14^{\circ} 04^{\prime} 12^{\prime \prime E}\right)$, along an altitude gradient ranging from $1502 \mathrm{~m}$ a.s.l. to $2309 \mathrm{~m}$ a.s.l. The spatial extension of the study area $\left(580 \mathrm{~km}^{2}\right)$ and the catchment areas of the individual lakes $\left(<9 \mathrm{~km}^{2}\right)$ are small (Fig. 1). Crystalline bedrock predominates, associated by schists and diagenetic or metamorphic carbonates. The lakes are not acidified (the lowest $\mathrm{pH}$ is 6.9). Glaciers are not present in the study area.

\section{MATERIAL AND METHODS}

\subsection{Diatom analysis}

Surface sediment samples $(0.5 \mathrm{~cm})$ were collected during the summer of 1999 from the deepest parts of the lakes with the use of a gravity corer. Samples ( $0.5 \mathrm{~g}$ wet sediment) for diatom analyses were treated through standard procedures (Battarbee 1986: $\mathrm{HCl}$ and $\mathrm{H}_{2} \mathrm{O}_{2}$, and repeated washing in distilled water; slides were prepared using Naphrax high resolution mountant). At least 


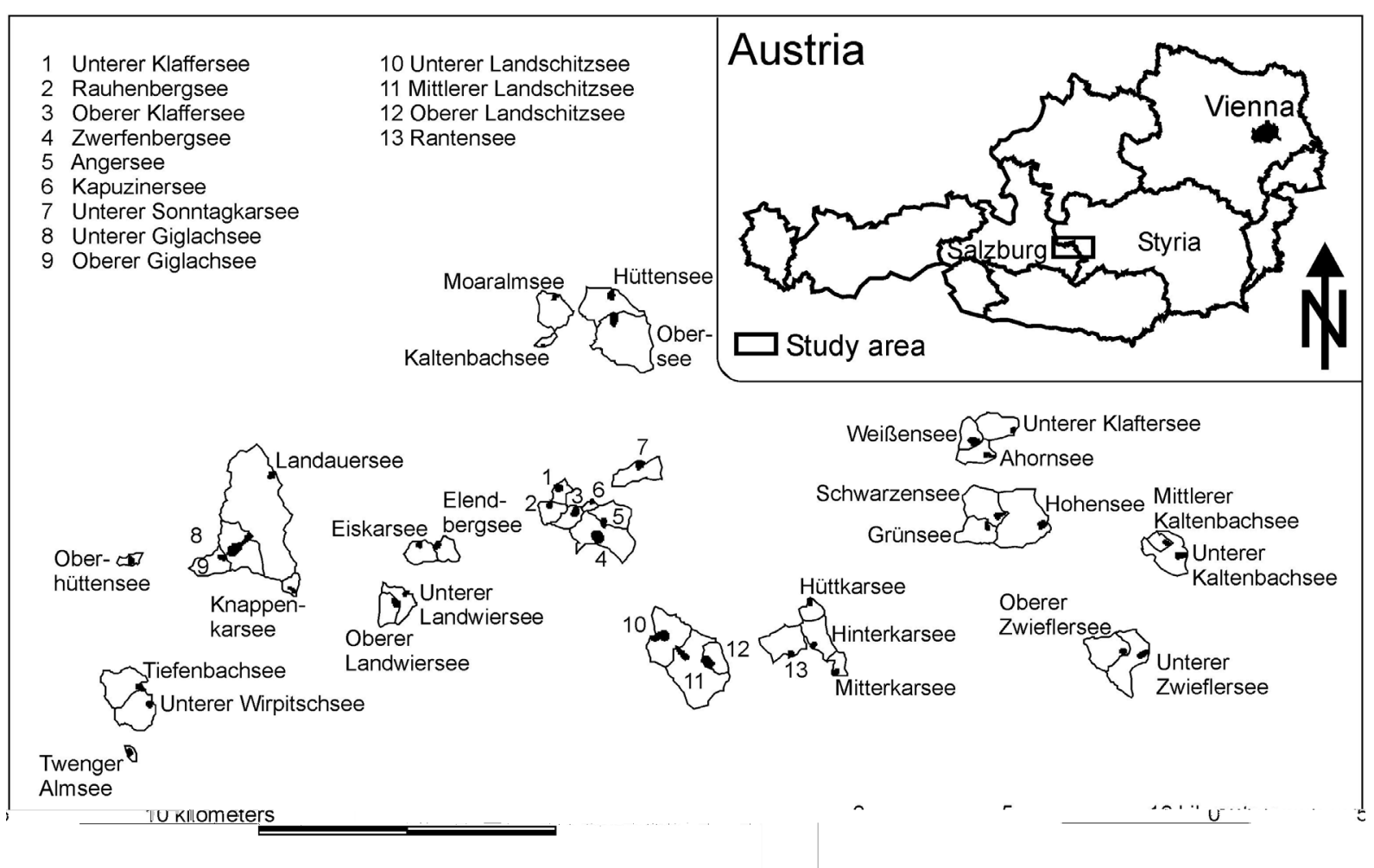

Fig. 1. Study area, geographic position, and catchments of the individual lakes located in the central Austrian Alps (Niedere Tauern).

500 diatom valves were counted using a Leitz microscope with $100 \times$ oil immersion and phase contrast objectives (PL APO 1.32). In addition to this total diatom set a subset of at least 500 valves of only Fragilaria and Staurosira (in the text called Fragilariaceae subset) was counted for an analysis of changes within these genera. Taxa that could not be differentiated in the LM, or with high numbers of broken valves, were grouped together. Valves in the girdle view that could not be assigned to a specific taxon were assigned among the taxa using the same \% relative abundance as the taxa identified by valve surfaces. For valve size measurements, the maximum length of the apical axis was measured. SEM studies were performed on a Hitachi S3000N.

\subsection{Environmental variables}

Maximum water depth $\left(Z_{\max }\right)$ was determined by echo sounding (FURUNO FE-4200). Relative water depth $\left(Z_{\text {rel }}\right)$ is a ratio of lake surface area to maximum water depth. Lake surface area was measured using digitized aerial photographs (resolution of $2 \mathrm{~m}$ ), using ArcView Spatial Analyst 3.1 (ESRI). Water temperature was measured in two hour intervals from July/August 1998 - September 1999 using 8 bit MINILOG - TR thermistors (VEMCO ltd.). Two thermistors per lake were placed between 1.4 and $3.3 \mathrm{~m}$ water depth. The depth of thermistor exposure could not be set more precisely, because of sediment-specific, technical, and logistic restrictions. Therefore, after the exposure, water temperature measurements were corrected for a standard depth of $2.3 \mathrm{~m}$ (i.e. the median water depth of exposure) by linear interpolation of the two thermistor readings. Water temperatures were not standardized for 6 lakes because only one logger could be retrieved. Seasonal and among lake variability, however, exceeded the temperature differences caused by varying exposure depths. These lakes were therefore retained in the study. During ice cover water temperatures were set to $0{ }^{\circ} \mathrm{C}$. This coding was necessary, because the measured water temperatures varied considerably within a lake at that time. The variation depended on whether the thermistors were frozen in the ice or not. If not, the distance between the thermistor and the ice cover had a major influence on the water temperature measurements. The corrected bihourly water temperature measurements were averaged for the months June - October $\left(\mathrm{T}_{\text {Jun }}-\mathrm{T}_{\text {Oct }}\right)$. Ice freezing (freeze) and break up dates (break) were estimated using temperature readings (Fig. 2). The reference dates 'date of spring mixing' $\left(\mathrm{S}_{\mathrm{mix}}\right)$ and 'date of autumn mixing' $\left(\mathrm{A}_{\text {mix }}\right)$ were defined as the first day after thawing or summer stratification when the mean daily water temperature was $4{ }^{\circ} \mathrm{C}$.

Water chemistry samples were taken with a PatalasSchindler sampler from a water depth of $2.5 \mathrm{~m}$ on the $18^{\text {th }}$ and $19^{\text {th }}$ of October 1999 , which were sampled by means of a helicopter hovering over the lake. Conductivity and $\mathrm{pH}$ were measured in the field (Mettler Toledo M125 and M126). Alkalinity was measured by Gran titration. Main anions (sulfate, nitrate and chloride) and cations (calcium, magnesium, sodium and po- 
tassium) were analyzed with ion chromatography (Dionex DX-120). Samples were filtered at the same day of collection using Whatman GF/C glass fiber filters with a pore width of $<0.45 \mu \mathrm{m}$. Ammonium, total dissolved reactive silica (DRSi), total dissolved $\left(\mathrm{P}_{\mathrm{dis}}\right)$ and total $\left(\mathrm{P}_{\text {tot }}\right)$ phosphorus (after digestion with sulfuric acid and hydrogen peroxide) were analyzed spectrophotometrically (Hitachi U-2000). Particulate phosphorus $\left(\mathrm{P}_{\text {part }}\right)$ was calculated from the total phosphorus minus total dissolved phosphorus. Total dissolved nitrogen (DN) was measured after digestion with sodium peroxodisulfate at $120{ }^{\circ} \mathrm{C}$ and the reduction of nitrate to nitrite by passage through a cadmium-copper column. Ammonium and nitrate were summarized as total inorganic nitrogen (TIN) for all statistical analyses to take into account their transformation by oxidation and reduction. Dissolved organic carbon (DOC) was measured with a high temperature combustion method on platinum wire (Shimadzu TOC 5000).

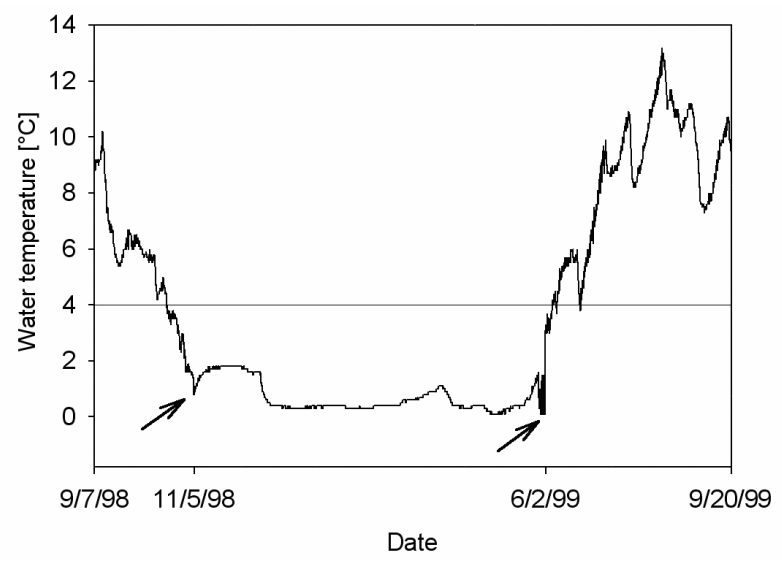

Fig. 2. Example of a lake water temperature record. Temperature curve from Hinterkarsee, situated 2,074 $\mathrm{m}$ a.s.l. and exposed to the south. Dates of the beginning and end of temperature readings (thermistors), freeze and break up (arrowed), and autumn and spring mixing (lined) are shown.

\subsection{Multivariate statistics}

All parameters, except $\mathrm{pH}$, were $\log _{10}$ transformed to avoid skewed distributions. Ice freeze and break up dates, as well as the dates $\mathrm{S}_{\text {mix }}$ and $\mathrm{A}_{\text {mix }}$ were expressed as Julian days. Diatom relative abundances were square root transformed to stabilize their variances (ter Braak \& Šmilauer 2002). Taxa with a maximum abundance of $<1 \%$ and occurrences in only one lake were disregarded.

Principal Components Analysis (PCA) was used to display the main gradients in the environmental parameters. A preliminary detrended correspondence analysis (DCA with detrending by segments) on the diatom assemblages (DA) resulted in a gradient length of 2.6 standard deviation units, suggesting the appropriateness of unimodal versus linear ordination methods (ter Braak 1987; Birks 1995). The DA were screened for outliers using correspondence analysis (CA). Within the
Fragilariaceae subset three lakes were dominated by one species (Mittlerer Kaltenbachsee, Tiefenbachsee, Twenger Almsee; abundance of $>90 \%)$. They were made passive in all of the analyses (i.e. they were retained, but had no influence on the result). Ordinations were performed using the program CANOCO 4.5 (ter Braak \& Šmilauer 2002). A series of Canonical Correspondence Analyses (CCA), constrained to a single environmental variable at a time in order to examine the influence of each variable on the DA (marginal effects), as well as partial CCAs were used to analyze species environment relationships (ter Braak 1987; Borcard et al. 1992). The significance of PCA and CA axes was tested using the broken stick model (Jackson 1993). The significance of environmental variables on the DA was evaluated using Monte Carlo permutations (9,999 unrestricted permutation cycles, reduced model; ter Braak \& Šmilauer 2002). Probability values were adjusted for multiple testing $\left(\mathrm{P}_{\mathrm{adj}}\right)$ using a Bonferroni-type test procedure (Hochberg 1988). The response of individual taxa to selected environmental variables was tested by Huisman-Olff-Fresco-models (Huisman et al. 1993) with maximum likelihood, using the program HOF (J. Oksanen, unpublished program). Bootstrapped species optima were calculated by the program C2 (Juggins 2003).

\section{TAXONOMY}

The taxonomy of the polymorphic family of Fragilariaceae is controversial (see e. g. Lange-Bertalot 1980; Williams \& Round 1986, 1987; Krammer \& LangeBertalot 1991, 2000). We followed the concepts presented by Krammer \& Lange-Bertalot (2000) that were modified by Lange-Bertalot \& Compére (2001). The taxa of the two genera Fragilaria Lyngbye and Staurosira Ehrenberg are listed in table 1. Basionyms and synonyms are added to appoint taxonomic names that are still in common usage. Additionally, the following remarks together with illustrations should help to appoint taxa that might be difficult to distinguish or that their taxonomy is uncertain:

\section{FRAGILARIA Lyngbye \\ Fragilaria delicatissima Lange-Bertalot}

Fragilaria delicatissima (Figs 3a-c) differed in the LM from $F$. nanoides Lange-Bertalot (Fig. 3d; LangeBertalot \& Metzeltin, 1996, Tab. 109, Figs $2-6$ ) by more distinct capitate poles, less dense striae $(<18 / 10$ $\mu \mathrm{m})$, marginal spines that reach the poles, a more illuminated light refraction in the phase contrast (probably due to a heavier silicification), and the occurrence of cell pairs (cells that have not separated following vegetative division). According to Krammer \& Lange-Bertalot (1991) $F$. delicatissima differs by the more spindle-like form and the less dense $(14-16 / 10 \mu \mathrm{m})$, finer, striae from $F$. tenera (W. Smith) Lange-Bertalot. 
Tab. 1. Species list (following the concepts of Krammer \& Lange-Bertalot 2000, and Lange-Bertalot \& Compére 2001) with abbreviations, basionyms and synonyms. * Rare species not included in the multivariate statistics.

\begin{tabular}{|c|c|c|c|}
\hline Taxa & Abbreviations & Basionyms & Synonyms \\
\hline \multicolumn{4}{|l|}{ *Fragilaria alpestris Krasske } \\
\hline F. amphicephala (Kütz.) Lange-Bertalot & Famp & Synedra amphicephala Kützing & $\begin{array}{l}\text { Fragilaria capucina ssp. amphicephala } \\
\text { (Kütz.) Lange-Bertalot }\end{array}$ \\
\hline F. arcus (Ehrenb.) Cleve & Farc & Navicula arcus Ehrenberg & $\begin{array}{l}\text { Ceratoneis arcus (Ehrenb.) Kützing, } \\
\text { Hannaea arcus (Ehrenb.) Patrick }\end{array}$ \\
\hline${ }^{*} F$. austriaca (Grun.) Lange-Bertalot & & $\begin{array}{l}\text { Synedra amphicephala var. austriaca } \\
\text { Grunow }\end{array}$ & $\begin{array}{l}\text { Fragilaria capucina var. austriaca } \\
\text { (Grunow) Lange-Bertalot }\end{array}$ \\
\hline F. capucina Desmazieres & Fcap & & \\
\hline F. danica (Kütz.) Lange-Bertalot & Fdan & Synedra danica Kützing & $\begin{array}{l}\text { Synedra ulna var. danica (Kütz.) Van } \\
\text { Heurck }\end{array}$ \\
\hline \multicolumn{2}{|c|}{ F. delicatissima (W. Smith) Lange-BertalotFdel } & Synedra delicatissima W. Smith & \\
\hline F. cf. exiguiformis Lange-Bertalot & Fexi & $\begin{array}{l}\text { Fragilaria virescens var. exigua } \\
\text { Grunow }\end{array}$ & $\begin{array}{l}\text { Fragilaria exigua (Grun.) Krammer \& } \\
\text { Lange-Bertalot, Stauroforma exiguiformis } \\
\text { Flower } \text { et al. }\end{array}$ \\
\hline F. gracilis Oestrup & Fgrac/nano (Group) & & $\begin{array}{l}\text { Fragilaria capucina var. gracilis } \\
\text { (Oestrup) Hustedt }\end{array}$ \\
\hline F. nanana Lange-Bertalot & Fnan & Synedra nana Meister & \\
\hline $\begin{array}{l}\text { F. nanoides Lange-Bertalot } \\
* F \text {. opacolineata Lange-Bertalot }\end{array}$ & Fgrac/nano (Group) & & \\
\hline F. parasitica (W. Smith) Grunow & Fpar & Odontidium parasiticum W. Smith & $\begin{array}{l}\text { Synedra parasitica }(\mathrm{W} . \text { Smith) Hustedt, } \\
\text { Synedrella parasitica } \text { Round \& Maidana }\end{array}$ \\
\hline
\end{tabular}



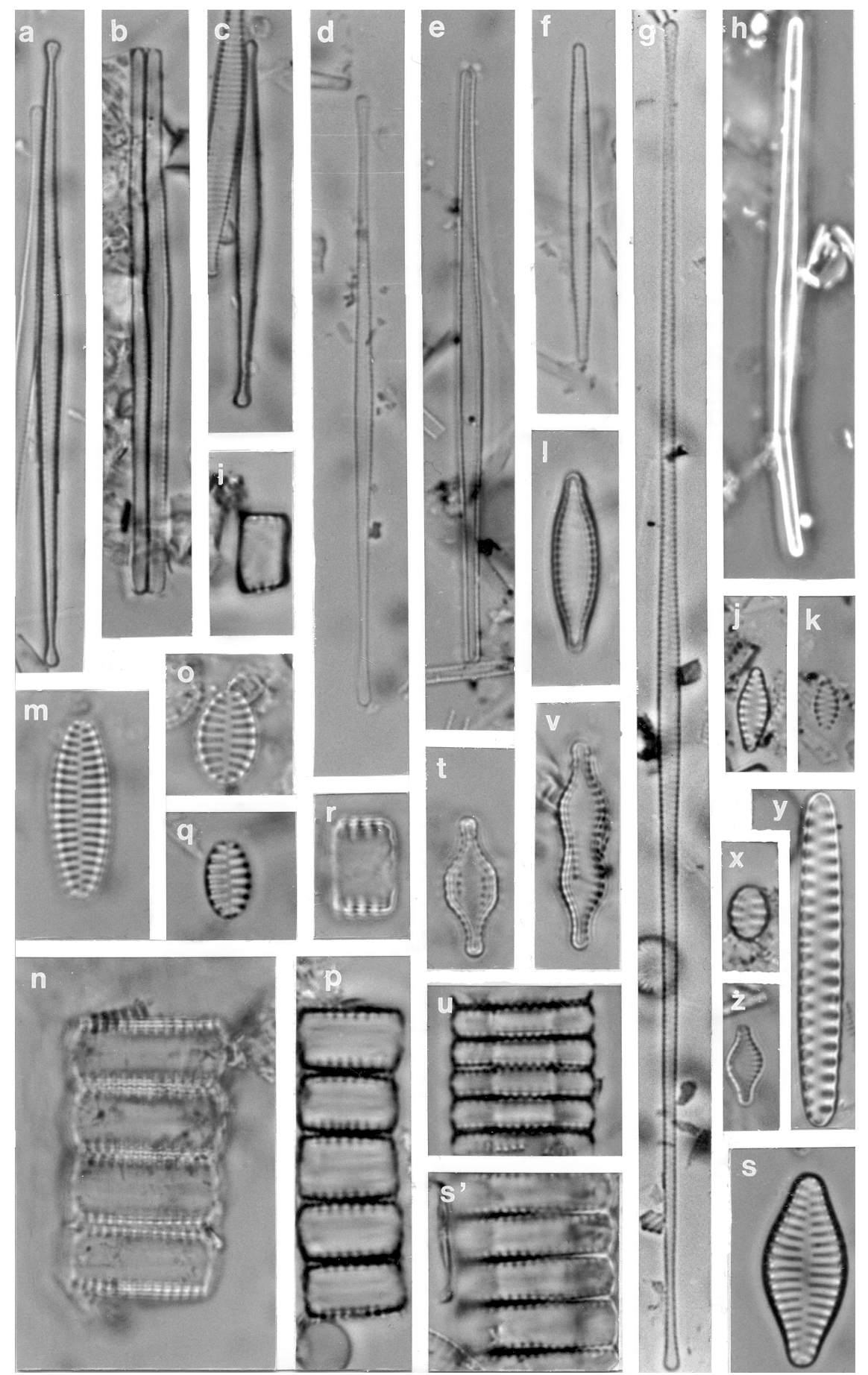

Fig. 3. LM photographs of selected diatom taxa (magnification 1,200×). 3a-c. Fragilaria delicatissima. Valve face (Fig. 3a); cell pair in girdle view (Fig. 3b); smaller-sized valve in valve face (Fig. 3c). 3d. Fragilaria nanoides in valve face. 3e-f. Fragilaria gracilis. Elongated (Fig. 3e) and smaller-sized (Fig. 3f) valves in valve faces. 3g. Fragilaria spec. 1 in valve face. $3 \mathbf{h}$. Fragilaria nanana in valve face (phase contrast). 3i. Species 2 in girdle view. 3j-l. Staurosira microstriata (Fig. 3j), small-sized morphotype (a) (Fig. 3k), and (b) Staurosira cf. microstriata in valve face (Fig. 31). 3m-r. Staurosira aff. venter. Elongated morphotype (1a) in valve face (Fig. 3m) and girdle view (Fig. 3n); Broadly-elliptical morphotype (1b) in valve face (Fig. 3o) and girdle view (Fig. 3p); small-sized morphotype (1c) in valve face (Fig. 3q) and girdle view (Fig. 3r). Note the rows of decernable mantle areoli in girdle views in contrast to Species 2 (Fig. 3i). See correspondent to figure 3r the SEM figure 5d. Morphotype with protruded poles (Fig. 3s). 3s'. "Girdles parallel" (S. aff. venter, see figure 3s, or S. pseudoconstruens). 3t-v. Staurosira robusta. Morphotypes with parallel contours (a) in valve face (Fig. 3t) and girdle view (Fig. 3u), and distinctly concave (b) (Fig. 3v) central contours in valve face. 3x, y. Staurosira pinnata s.l. Staurosira pinnata var. subrotundata (Fig. 3x) and S. pinnata var. intercedens (Fig. 3y) in valve faces. 3z. Staurosira parasitoides in valve face. 

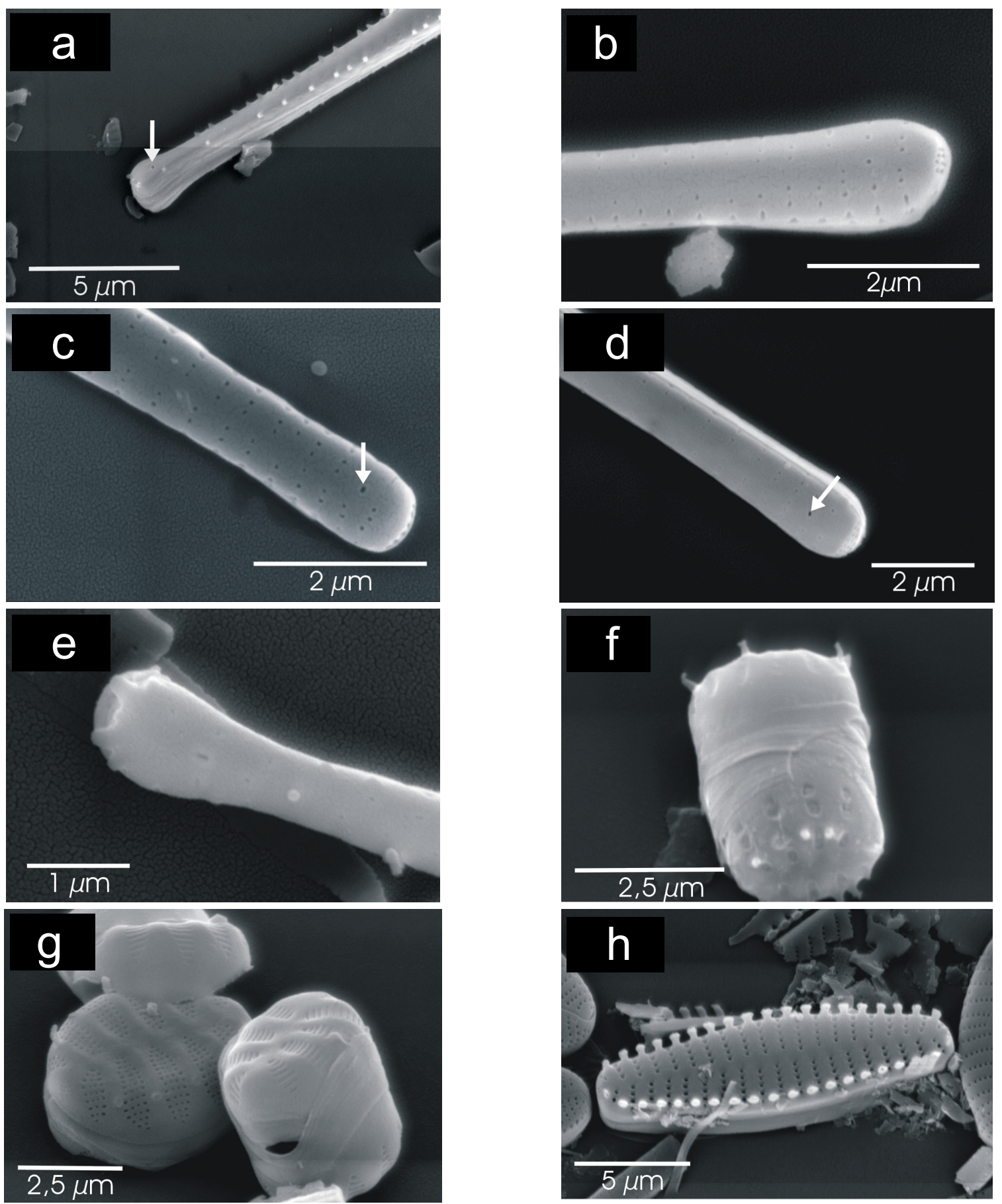

Fig. 4. SEM micrographs of selected diatom taxa. 4a. Polar part of Fragilaria delicatissima showing the spine-formation and the external opening of the rimoportula (arrowed). 4b. Polar part of Fragilaria nanoides with apical pore-field. 4c. Polar part of Fragilaria gracilis with the external opening of the rimoportula (arrowed), and the presence of an apical pore-field. 4d. Polar part of Fragilaria nanana showing the external opening of the rimoportula (arrowed). 4e. Polar part of Fragilaria spec. 1 showing the external opening of the rimoportula and the apical horn-like appendices. $\mathbf{4 f}$. Species 2? Side view and part of the valve surface. $\mathbf{4 g}$. Staurosira pinnata var. subrotundata (right) and Punctastriata ovalis (left). Note transitions between punctate and "pinnate" structure of alveoli in the taxon at right from one and the same sample. $4 \mathbf{h}$. Staurosira aff. venter (2) in side view. 
In the SEM the marginal spines of $F$. delicatissima are saw-tooth-like (Fig. 4a). A rimoportula is present near the end of at least one pole (Fig. 4a). Both lack in $F$. nanoides (Fig. 4b).

\section{Fragilaria gracilis Oestrup and Fragilaria nanoides Lange-Bertalot}

In the LM, elongated valves of $F$. gracilis (Fig. 3e) mainly differ from $F$. nanoides, at least by the less distinct capitate valves, median parallel (towards the poles the striae are also offset on either sides of the valve as in the entire valve of $F$. nanoides), and the coarser (18$20 / 10 \mu \mathrm{m})$ striae. The smaller-sized valves of $F$. gracilis greatly differ from $F$. rumpens by the median parallel striae, which are also offset in the latter.

In the SEM, both taxa showed no marginal spines towards the poles (Figs 4b, c). The polar pore field of $F$. gracilis consists of one row of porelli (Fig. 4c) whereas $F$. nanoides has two rows (Fig. $4 b$ ). $F$. gracilis, in contrast to $F$. nanoides, showed a rimoportula (Figs $4 \mathrm{~b}, \mathrm{c}$ ).

Because of fragmentation of larger-sized valves, we combined the taxa $F$. gracilis and $F$. nanoides into one group (F. grac/nano).

\section{Fragilaria nanana Lange-Bertalot}

Fragilaria nanana differs in LM from $F$. gracilis and $F$. nanoides by the more narrow (median $1.5-2$ $\mu \mathrm{m})$, needle-like valves that appear to be more silicified (Fig. 3h), and the very tiny striae that are difficult to resolve.

According to SEM (Fig. 4d) towards the top of the valve no striae occur or if so they are restricted to tiny marginal areolae.

\section{Fragilaria spec. 1}

The strongly elongated $(>100 \mu \mathrm{m})$, needle-like (Fig. $3 \mathrm{~g}$ ), slightly capitate valves with central indistinct striae are similar to those commonly referred in the literature as Synedra acus var. angustissima Grunow. The number of striae ranged from 15 to 18 in $10 \mu \mathrm{m}$.

In the SEM (Fig. 4e) the slightly enlarged poles show horn-like appendices and the opening of a rimoportula. Only single, elliptically elongated areolae (10 in $10 \mu \mathrm{m}$ ) occur at the valve margins towards the end of the valves. These characters clearly distinguish Fragilaria spec 1 from $F$. nanoides (see Fig. 4b).

\section{Fragilaria (Stauroforma) cf. exiguiformis}

In the SEM (Figs $5 \mathrm{~g}$ and $\mathrm{h}$ ) the valve morphology corresponds with illustrations from Flower et al. (1996) for the spinose (the spines are also visible in LM, Figs $5 \mathrm{e}, \mathrm{f}$ ) form of Fragilaria exiguiformis (Grun.) LangeBertalot. The valves in our material are, however, distinctly larger $(23.7-44.8 \mu \mathrm{m})$ than mentioned in Flower et al. (1996) for European populations of Stauroforma exiguiformis $(13.4-16.4 \mu \mathrm{m})$.

\section{STAUROSIRA Ehrenberg}

\section{Staurosira aff. venter}

1) Elliptical valves with distinctly raised costae which bear marginal spines; in the LM the striae (12 to 15 in $10 \mu \mathrm{m})$ are punctate; in the SEM the areolae are elliptically-elongated and increase in size from the valve center towards the valve margin and mantle. Size ranged from $5.4 \mu \mathrm{m}$ to $17.4 \mu \mathrm{m}$. Three different morphotypes were distinguished and counted separately:

a) elongated valves $>12 \mu \mathrm{m}$ in length (Figs $3 \mathrm{~m}$ and $\mathrm{n}$; $5 \mathrm{a}, \mathrm{b})$

b) broadly-elliptical valves 7.5 to $12 \mu \mathrm{m}$ in length (Figs $3 \mathrm{o}$ and $\mathrm{p} ; 5 \mathrm{c})$;

c) small valves $<7.5 \mu \mathrm{m}$ (Figs $3 \mathrm{q}$ and $\mathrm{r}$; 5d).

The small valves differ from the former by the window-like areolae on the broadly enlarged mantle (Fig. $5 \mathrm{~d}$; also visible in LM, Fig. 3r), sometimes showing a grill-like microstructure in the SEM. More than two apical rows of areolae occur on the enlarged mantle that is also visible in LM (Fig. 3r).

At the present stage it is unclear as to whether all of the three morphotypes $(1 \mathrm{a}-\mathrm{c})$ belong to one and the same species. Morphotypes which possess coarser areolae resemble Fragilaria elliptica in the sense of some authors, but the type of Fragilaria elliptica Schumann is unknown and seem to be lost (Krammer \& Lange-Bertalot 1991). Fragilaria (Staurosira, see Krammer \& Lange-Bertalot 2000) neoelliptica was described by Witkowski (1994) from a brackish environment, and hence differs distinctly in the autecology from the Alpine populations. In the SEM (Fig. 5c) the broadly elliptical morphotype (1b) is similar to Staurosira aventralis that was described by Lange-Bertalot and Rumrich in Rumrich et al. (2000) from the Andes (3300 m a.s.1.). Similar taxa might be identified under the name of Fragilaria construens var. venter Ehrenberg (for its combination with Staurosira see Hamilton et al. 1992).

2) Elliptical elongated valves as in morphotype $1 \mathrm{a}$. From the latter they differ, however, by the less raised costae, the smaller, rounded areolae of more or less the same size (SEM) that are not discernible in LM, in addition by only one row of mantle areolae (Fig. 4h).

3) Valves with distinctly protruded poles (Fig. 3s). It is unclear if the single valve surfaces which were found belong to girdle views showing valves with a parallel or convex median part and distinctly narrowed polar parts (Fig. 3s') or to Staurosira pseudoconstruens. Hence, they were counted separately ("girdles parallel").

\section{Staurosira? Species 2}

This taxon has small valves $(<7 \mu \mathrm{m})$ with distinctly elongated, barrel-like, girdle views (Fig. 3i). Valve sur- 

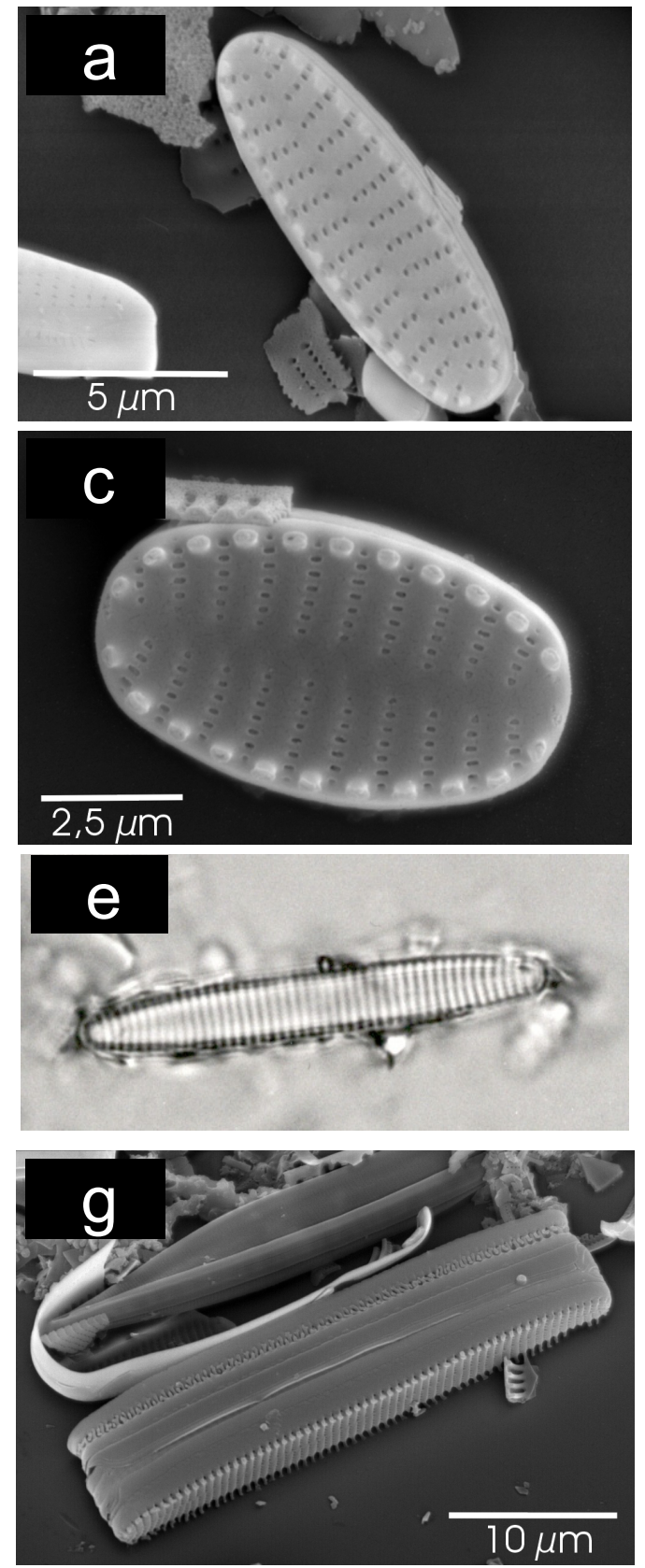
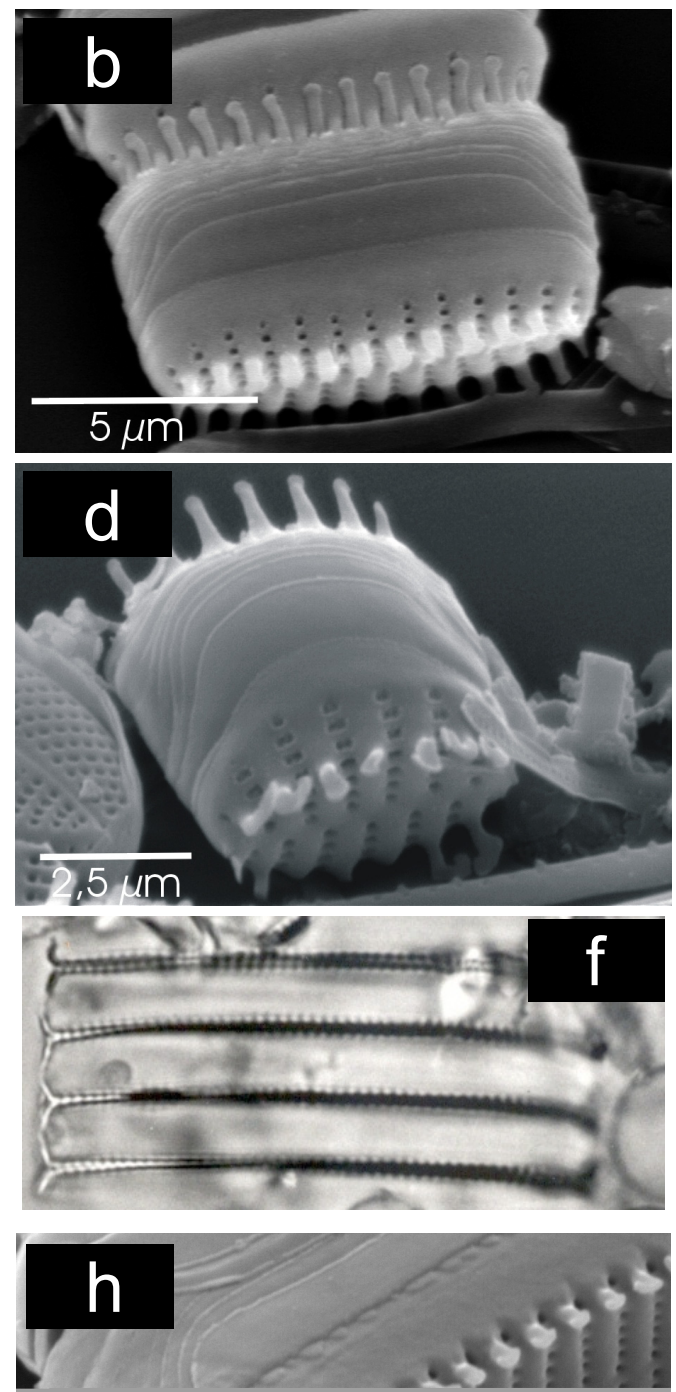

Fig. 5. SEM micrographs of selected diatom taxa (continued). 5a-d. Staurosira aff. venter (1). Elongated morphotype (a) in valve (Fig. 5a) and girdle view (Fig. 5b); Broadly-elliptical morphotype (b) in valve view (Fig. 5c); Small-sized morphotype (c) in girdle view (Fig. 5d). Note the 3-4 rows of rectangular-elongated areolae on the enlarged valve mantle. 5e-h. F. cf. exiguiformis. Valve face (Fig. 5e) and girdle view (Fig. 5f) in LM; Side overview (Fig. 5g) and polar part (Fig. 5h) in SEM.

faces might be confused with the small morphotype (a) of $F$. microstriata illustrated in figure $3 \mathrm{k}$. The marginal spines and striae of Species 2 are, however, offset, whereas in F. microstriata (a), as characteristic for the $F$. brevistriata complex, mantle areolae (lacking in Species 2), marginal spines, and ghost striae are arranged in one row (see Schmidt et al. 2004).

It is unknown if the barrel-like valve illustrated in the SEM (Fig. 4f) that was found together with Species 2 belongs to the same species. The valve surface under the SEM showed partly punctate alveoli. Marginal spines may be branched or anchor-like. The valve mantle is ornamented by low depressions.

Staurosira microstriata (Marciniak) Lange-Bertalot and Staurosira parasitoides Lange-Bertalot et al.

Both taxa were studied and illustrated in detail by Schmidt et al. (2004). They are characterized by the presence of the so-called "ghost striae" (Lange-Bertalot \& Metzeltin 1996), which means that the marginal areolae characterizing the $S$. brevistriata complex con- 
tinue channel-like towards the valve center. In this feature and probably also in ecological preferences (see discussion) both taxa differ from other taxa of the Fragilaria brevistriata complex. S. microstriata was differentiated into two morphotypes which were counted separately: Small $(<7.5 \mu \mathrm{m})$ boat-shaped valves (a) (Fig. 3k; see Schmidt et al. 2004, Fig. 10), and larger valves (b) $(>15 \mu \mathrm{m})$ showing the same microstructure as $S$. microstriata noted as $F$. cf. microstriata by Marciniak (1988) (Fig. 31).

$S$. parasitoides (Fig. 3z) differs from S. microstriata by its broadly fusiform bulbous shape, small conical, densely crowded marginal spines, and additional areolae in the enlarged part of the valve surface.

\section{Staurosira pinnata s. 1.}

Three groups were distinguished and enumerated separately.

a) Small $(<7.5 \mu \mathrm{m})$, broadly elliptical valves which probably correspond with $F$. pinnata var. subrotundata A. Mayer (Fig. 3x). According to SEM studies (Fig. 4g) small valves co-occurred with the former which conform to Punctastriata ovalis as described by Williams \& Round (1987). Since the areolate alveoli of the latter could not be differentiated in LM from the transapically elongated alveoli structure of the small $F$. pinnata specimens, and in the SEM both structures could be observed in one and the same sample (Fig. 4g), both forms were combined in this group.

b) Mid-sized valves, $7.5-13 \mu \mathrm{m}$, occurred in two morphotypes, elliptical and slightly heteropolar valves.

c) Large $(>13 \mu \mathrm{m})$ cigar-like, elongated valves. Within a single sample, valves were found that differed in width of the axial area from 1 to $2.5 \mu \mathrm{m}$. Valves with enlarged axial area correspond with $F$. pinnata var. intercedens (Grunow) Hustedt (Fig. 3y).

\section{Staurosira robusta (Fusey) Lange-Bertalot}

Two morphotypes were differentiated; (a) valves with more or less parallel sides (Figs 3t, u), and (b) those formerly described as $F$. pseudoconstruens fo. bigibba Marciniak which are characterized by distinctly concave valves (Fig. 3v).

\section{RESULTS}

\subsection{Environmental variables}

Geographical, morphological, and limnological features of the 40 study lakes are summarized in table $2 \mathrm{~A} / \mathrm{B}$. These variables could be assigned to 4 major environmental gradients, (1) climate (PCA axis 1), (2) nutrients (PCA axis 2), (3) catchment characteristics (bedrock mineralogy and vegetation cover; PCA axis 3 ), and (4) water depth (PCA axis 4, Tab. 3). The four signifi- cant PCA axes explained $75.2 \%$ of the variation in the abiotic variables.

The physical variables (water temperature, ice cover, date of mixing) explained most of the variation in the environmental data-set (PCA axis 1: $34.7 \%$ ). Nutrients were largely independent from PCA axis 1 . Within the chemical variables that characterize nutrients (the phosphorus and nitrogen fractions, DOC, DRSi), dissolved phosphorus had a higher correlation with the PCA axis 1 than with PCA axis 2. DOC correlates with PCA axis 2 and 3, and shows some correlation with PCA axis 1 . Chemical variables characterizing bedrock mineralogy ( $\mathrm{pH}$, alkalinity, conductivity, $\mathrm{Ca}^{2+}, \mathrm{Mg}^{2+}$ and $\mathrm{SO}_{4}{ }^{2-}$ ) were also correlated with PCA axis 1 . Relative and, to a minor extent, absolute water depth were correlated with PCA axis 1 and 2.

\subsection{Diatom analysis}

A Correspondence Analysis (CA) on the total diatom assemblages resulted in three significant axes, explaining $33.7 \%$ of the variation. The Fragilariaceae were evenly spaced among the other diatoms (Fig. 6). Table 3 summarizes the amount of variation each environmental variable explained singly in a series of CCAs (marginal effects). Alkalinity and related variables $(\mathrm{pH}$, conductivity, $\mathrm{Ca}^{2+}, \mathrm{Mg}^{2+}$ ) explained most of the variation in the total diatom dataset and the Fragilariaceae subset. DOC had a significant $\left(\mathrm{P}_{\mathrm{adj}}<0.05\right)$ influence on the total diatom assemblage, but not on the Fragilariaceae subset. Among the weather related variables were that of the July water temperature, which had a significant influence on total diatom dataset, whereas the length of the ice cover significantly affected the Fragilariaceae subset. Both variables, however, were highly correlated. Among the variables that had significant marginal effects on the entire diatoms, $\mathrm{pH}$ and $\mathrm{T}_{\mathrm{Jul}}$ explained a significant unique (i.e., effects of other environmental variables removed) amount of variation (5.9\% and 5.3\%, respectively). The same analysis on the Fragilariaceae subset revealed, that only the length of the ice cover uniquely explained a significant amount of variation $(7.3 \%)$ within this subset. Conductivity was deleted prior to both analyses because of a high colinearity (VIF $>20$ ) with the other significant variables.

Variables characterizing the catchment (mineralogy and vegetation cover) were highly correlated with CA axis 1 (Fig. 6). Weather driven variables (water temperature, variables related to ice cover and mixing) were correlated with CA axis 2 (Fig. 6). DOC was correlated with both $\mathrm{CA}$ axes 1 and 2 . Water depth was correlated with $\mathrm{CA}$ axis 3. Figure 6 and 7 summarize species environmental variables relationships. The variables were included as passive environmental data in the CAs in which were selected according to their significance ( $P$ $<0.05$ ) for the entire diatom dataset and the Fragilariaceae subset (Tab. 3B). 


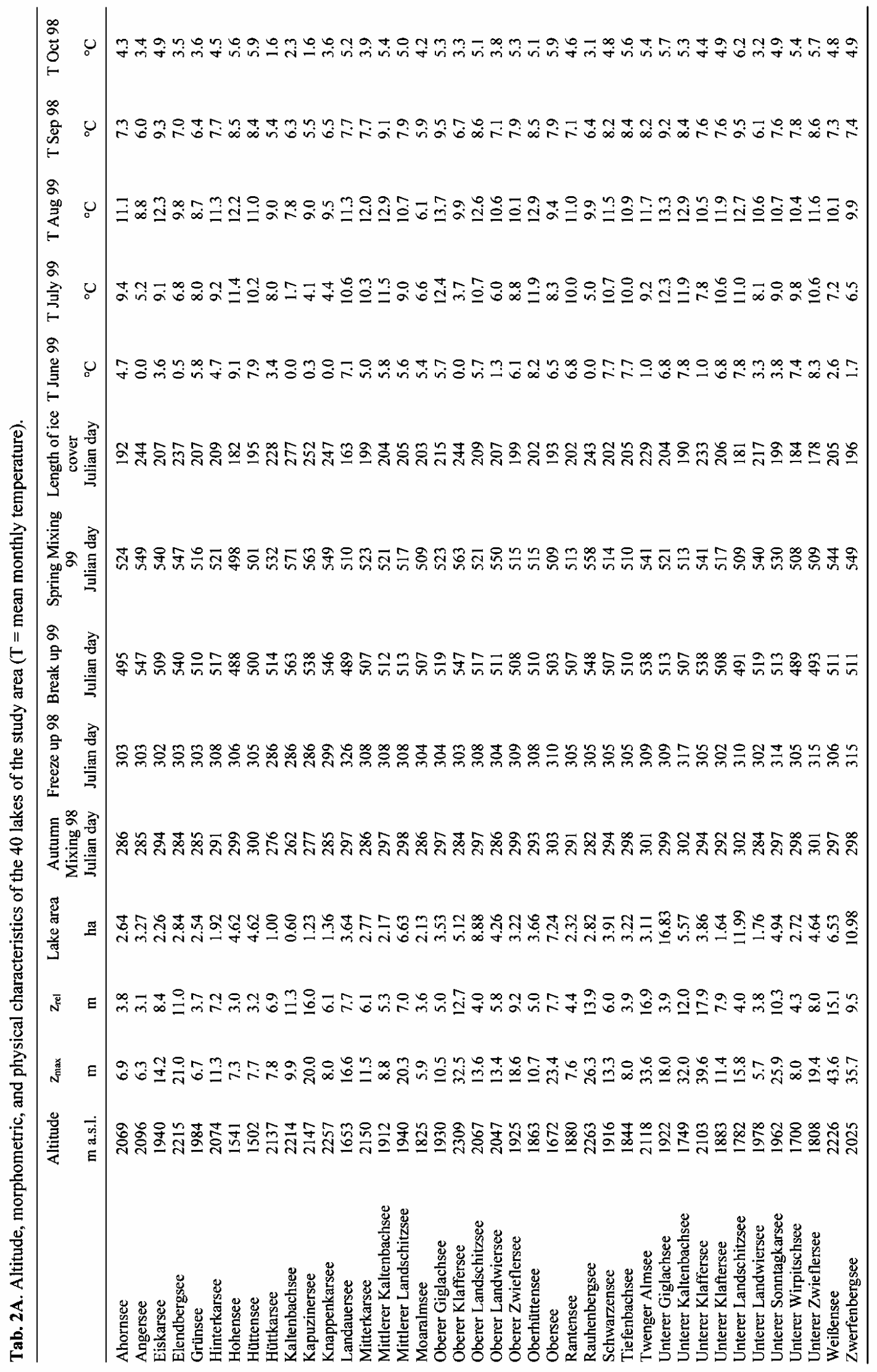




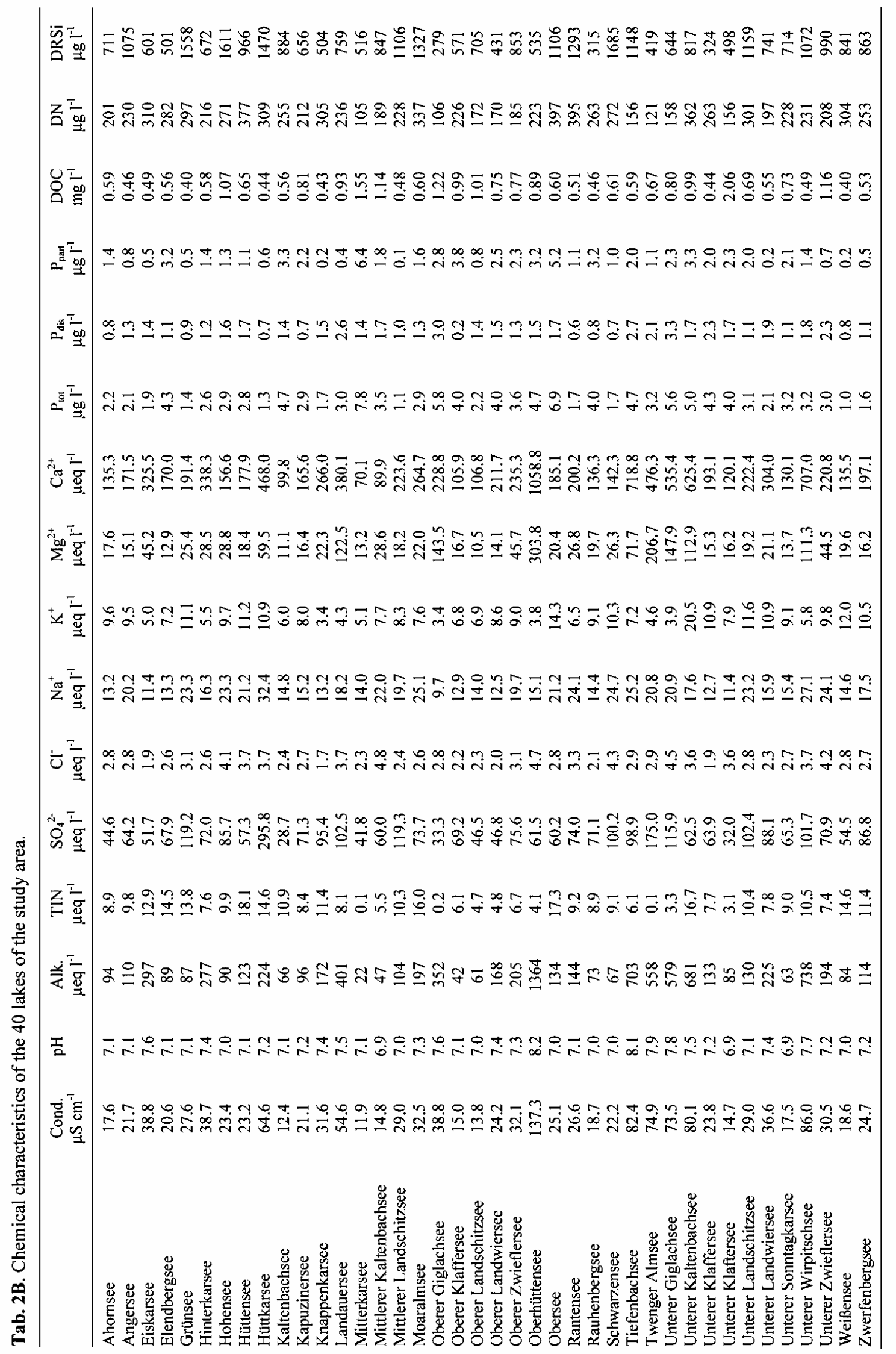


Tab. 3. (A). PCA axes $1-4$ scores (correlation coefficients with axes 1- 4) for the environmental variables listed in table 2 . The axes represent 4 significant gradients related to climate (axis 1), nutrients (axis 2), bedrock mineralogy and vegetation cover (axis 3 ) and water depth (axis 4). (B): Amount of variation explained singly (marginal effects) by each of the variables from table 2 on the total diatom assemblage, and the Fragilariaceae subset. Asterisks indicate a significant influence $(\mathrm{P}<0.05)$. Superscript $\mathrm{B}$ indicate significant $\mathrm{P}$ values $\left(\mathrm{P}_{\mathrm{adj}}<0.05\right)$ corrected for multiple testing.

\begin{tabular}{|c|c|c|c|c|c|c|}
\hline & \multicolumn{4}{|c|}{ (A) PCA } & \multicolumn{2}{|c|}{ (B) CCA: marginal effects $(\%)$} \\
\hline & axis 1 & axis 2 & axis 3 & axis 4 & all diatoms & Fragilariaceae \\
\hline Altitude & 0.80 & 0.31 & 0.17 & 0.09 & $4.52 *$ & $5.66^{*}$ \\
\hline \multicolumn{7}{|l|}{ Temperature } \\
\hline T June 99 & -0.89 & -0.23 & -0.22 & -0.18 & $5.75^{*}$ & $7.07 *$ \\
\hline T July 99 & -0.90 & 0.11 & -0.20 & -0.05 & $5.75^{\mathrm{B}}$ & $7.07 *$ \\
\hline T Aug 99 & -0.64 & 0.47 & -0.24 & 0.08 & $4.93 *$ & $6.36^{*}$ \\
\hline T Sep 98 & -0.74 & 0.34 & -0.30 & 0.18 & $4.93^{*}$ & $5.66^{*}$ \\
\hline T Oct 98 & -0.83 & 0.09 & -0.28 & 0.28 & $5.34 *$ & $7.07 *$ \\
\hline \multicolumn{7}{|c|}{ Ice Cover and Mixing } \\
\hline Autumn mixing 98 & -0.79 & 0.04 & -0.22 & 0.46 & $5.34 *$ & $6.36^{*}$ \\
\hline Freeze up 98 & -0.63 & 0.10 & -0.27 & 0.48 & $4.52 *$ & $7.07 *$ \\
\hline Break up 99 & 0.79 & 0.33 & 0.26 & 0.02 & $4.93^{*}$ & $7.07 *$ \\
\hline Spring mixing 99 & 0.87 & 0.30 & 0.21 & 0.16 & $5.34 *$ & $7.07 *$ \\
\hline Length of ice cover & 0.83 & 0.24 & 0.29 & -0.14 & $5.34 *$ & $8.49^{\mathrm{B}}$ \\
\hline \multicolumn{7}{|l|}{ Chemistry } \\
\hline Conductivity & -0.60 & 0.06 & 0.78 & 0.07 & $9.86^{\mathrm{B}}$ & $11.32^{\mathrm{B}}$ \\
\hline $\mathrm{pH}$ & -0.45 & 0.41 & 0.73 & -0.06 & $9.86^{\mathrm{B}}$ & $11.32^{\mathrm{B}}$ \\
\hline Alkalinity & -0.59 & 0.17 & 0.73 & 0.07 & $11.50^{\mathrm{B}}$ & $12.02^{\mathrm{B}}$ \\
\hline TIN & 0.14 & -0.75 & 0.01 & 0.18 & 4.52 & 1.41 \\
\hline $\mathrm{SO}_{4}{ }^{2-}$ & -0.19 & -0.43 & 0.58 & 0.20 & 2.87 & 2.12 \\
\hline $\mathrm{Cl}^{-}$ & -0.67 & -0.22 & -0.03 & -0.21 & 3.70 & 4.24 \\
\hline $\mathrm{Na}^{+}$ & -0.41 & -0.67 & 0.23 & -0.12 & 2.46 & 2.12 \\
\hline $\mathrm{K}^{+}$ & 0.08 & -0.58 & -0.34 & 0.32 & 3.29 & 4.24 \\
\hline $\mathrm{Mg}^{2+}$ & -0.67 & 0.29 & 0.59 & 0.02 & $7.80^{\mathrm{B}}$ & $8.49^{\mathrm{B}}$ \\
\hline $\mathrm{Ca}^{2+}$ & -0.54 & 0.03 & 0.80 & 0.09 & $10.68^{\mathrm{B}}$ & $11.32^{\mathrm{B}}$ \\
\hline $\mathrm{P}_{\text {tot }}$ & -0.18 & 0.66 & -0.17 & -0.21 & 2.87 & 2.83 \\
\hline $\mathrm{P}_{\mathrm{dis}}$ & -0.56 & 0.36 & 0.13 & -0.10 & $4.93 *$ & 4.95 \\
\hline $\mathrm{P}_{\text {part }}$ & -0.01 & 0.47 & -0.25 & -0.25 & 2.46 & 2.83 \\
\hline DOC & -0.35 & 0.50 & -0.51 & -0.28 & $6.16^{\mathrm{B}}$ & $6.36^{*}$ \\
\hline $\mathrm{DN}$ & 0.11 & -0.73 & 0.06 & 0.29 & 3.29 & 1.41 \\
\hline DRSi & -0.26 & -0.87 & -0.02 & -0.18 & 2.87 & 2.83 \\
\hline \multicolumn{7}{|l|}{ Water depth } \\
\hline $\mathrm{Z}_{\max }$ & 0.13 & 0.31 & -0.12 & 0.86 & $4.93 *$ & $5.66^{*}$ \\
\hline $\mathrm{Z}_{\mathrm{rel}}$ & 0.45 & 0.34 & 0.05 & 0.64 & $4.11 *$ & $5.66^{*}$ \\
\hline
\end{tabular}




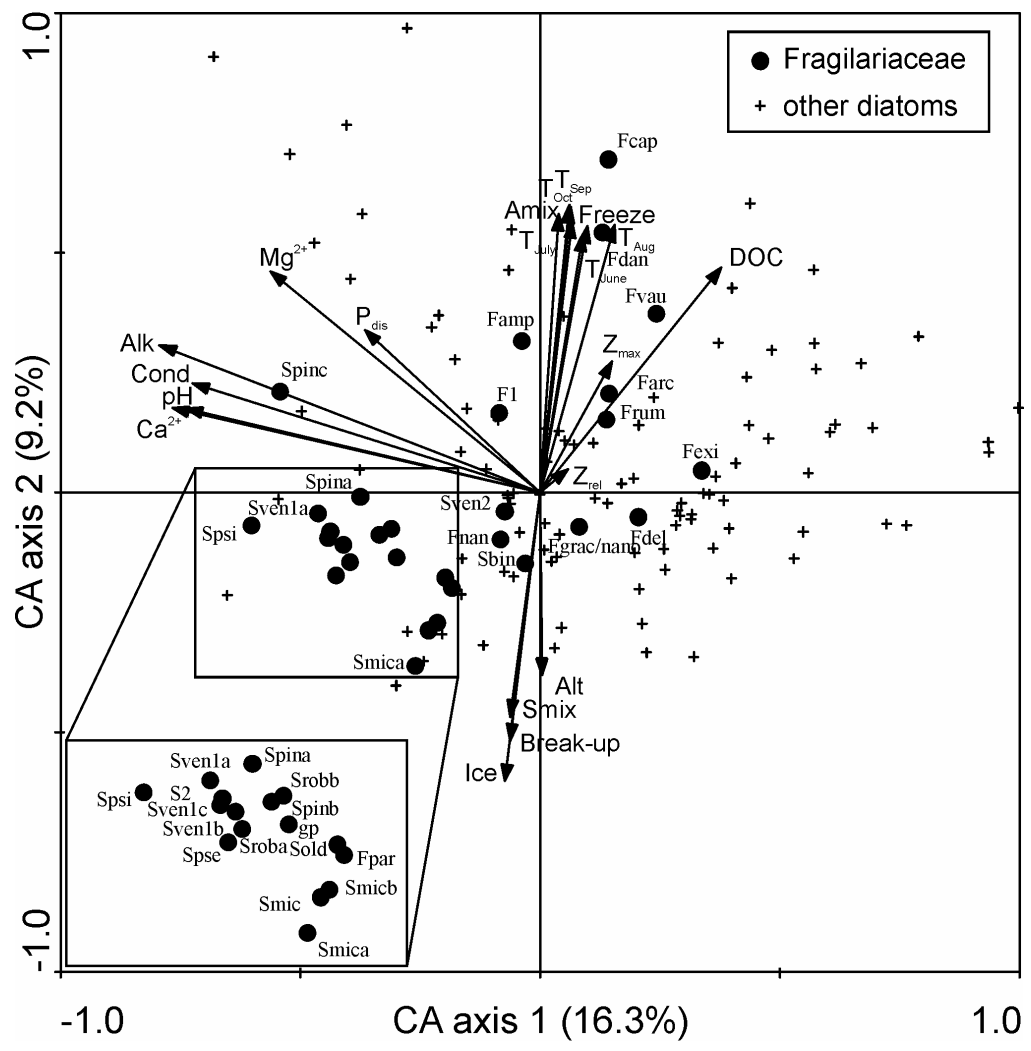

Fig. 6. Correspondence Analysis (CA) ordination biplot of the Niedere Tauern diatom training set with species scores of Fragilaria and Staurosira (for abbreviations see Tab. 1) and significant (marginal effects, $\mathrm{P}<0.05)$ passive environmental variables $($ Alk $=$ alkalinity, Alt = altitude, $\mathrm{A}_{\mathrm{mix}}=$ date of autumn mixing, Break-up = ice break up date, Cond = conductivity, DOC = dissolved organic carbon, Freeze $=$ date of freezing, ice $=$ duration of ice cover, ions, $\mathrm{pH}, \mathrm{S}_{\mathrm{mix}}=$ date of spring mixing, $\mathrm{T}_{\text {month }}=$ mean monthly temperature, $Z_{\max }=$ maximum water depth, $Z_{\text {rel }}=$ ratio of lake surface area/max. water depth). Percentages accounting for species variation at the first and second axis are added.

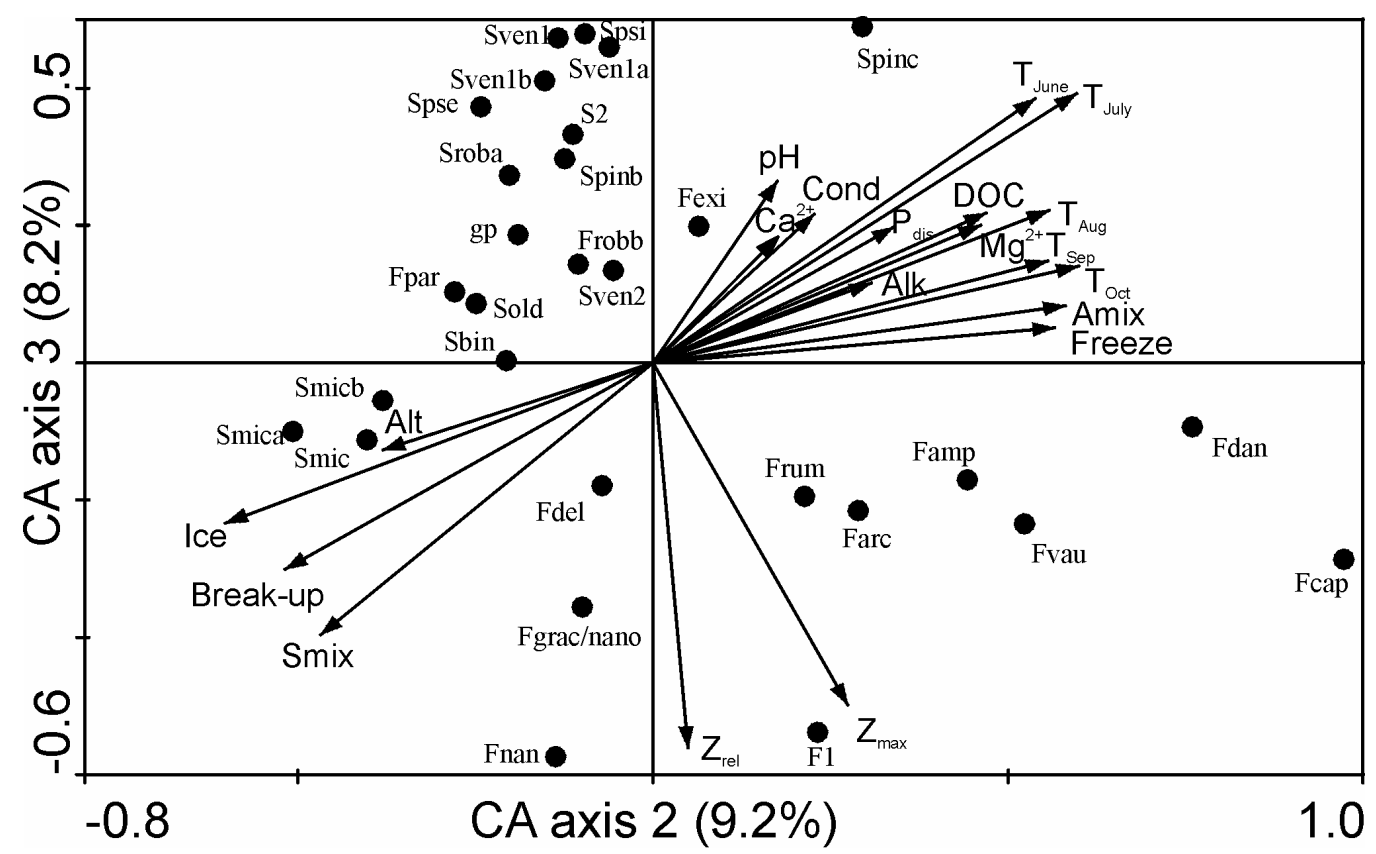

Fig. 7. Correspondence Analysis (CA) ordination biplot of the Niedere Tauern diatom training set with species scores of Fragilaria and Staurosira (for abbreviations see Tab. 1) and significant (marginal effects, $\mathrm{P}<0.05$ ) passive environmental variables (for abbreviations see Fig. 6). Percentages accounting for species variation at the second and third axis are added. 

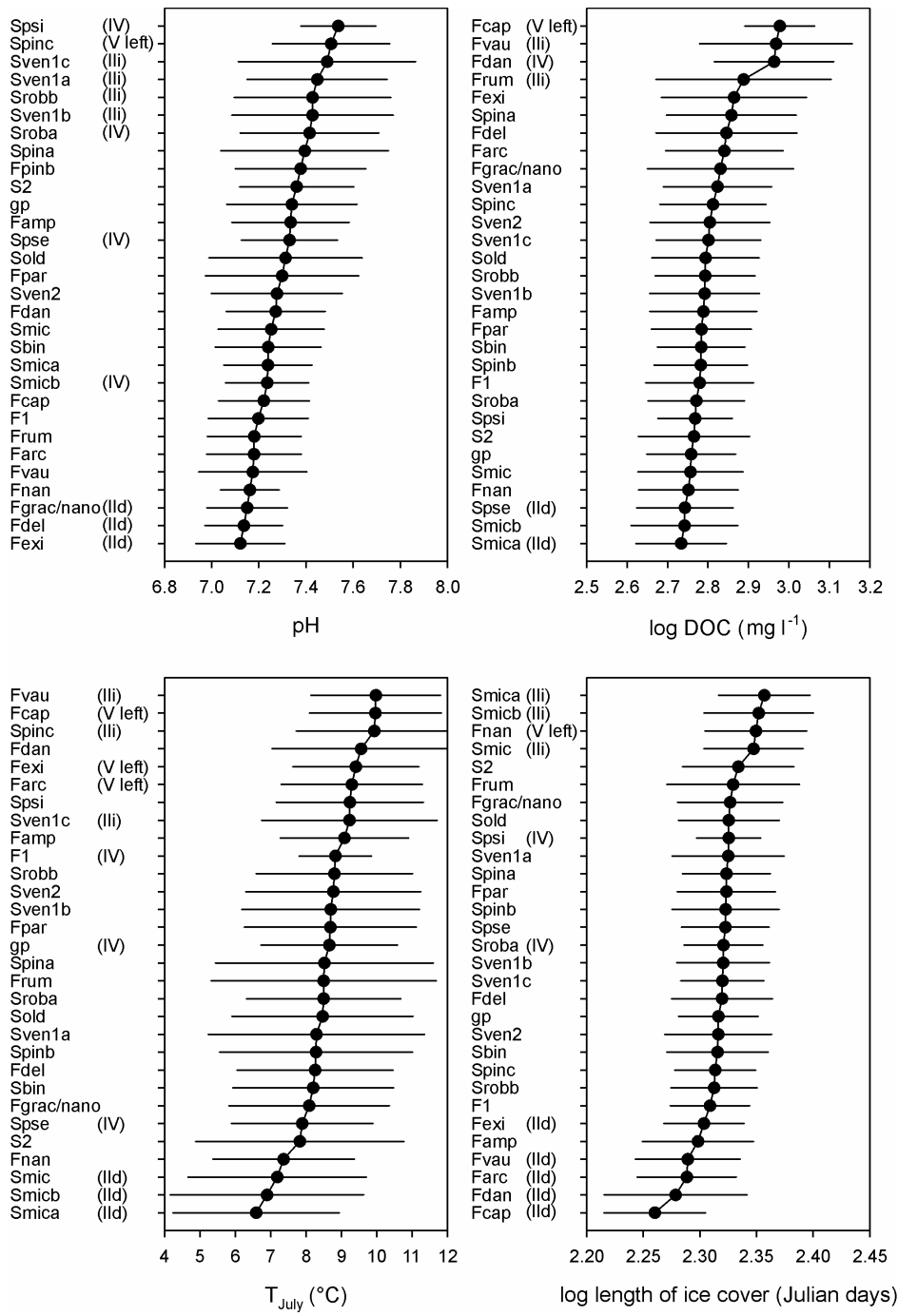

Fig. 8. Bootstrapped optima and tolerances of the main environmental variables for selected Fragilaria and Staurosira (for abbreviations see Tab. 1). Significant species response models are given in brackets (V: skewed unimodal response;. IV: symmetric Gaussian unimodal; II i: monotonically increasing sigmoidal response model; II d: monotonically increasing sigmoidal response model).

\subsection{Ecology of diatom taxa}

In figure 8 the taxa were arranged according to their bootstrapped optima within the range of the 4 main environmental variables (see Fig. 6). The taxa significantly $(\mathrm{P}<0.05)$ responding to the selected environmental variables were:

A) Taxa responding to $\mathrm{pH}$ (range 6.9 to 8.2 ; in increasing order) were:

$F$. cf. exiguiformis, $F$. delicatissima, $F$. gracilis/ nanoides, $S$. cf. microstriata (b), S. pseudoconstruens, S. robusta (a), S. aff. venter (1b), $S$. robusta (b), $S$. aff. venter (1a and 1c), S. pinnata var. intercedens (c), S. parasitoides.

B) Taxa responding to mean July water temperature ( $\mathrm{T}_{\text {july }}$ ) (range $1.7-12.4{ }^{\circ} \mathrm{C}$; in increasing order) were:
S. microstriata (a), S. cf. microstriata (b), S. microstriata, S. pseudoconstruens, "girdles parallel", $F$. spec. $1, S$. aff. venter (1c), $F$. arcus, $F$. cf. exiguiformis, $S$. pinnata var. intercedens (c), F. capucina, F. vaucheriae.

C) Taxa responding to the length of ice cover (range 163 - 277 days; in increasing order) were:

$F$. capucina, $F$. danica, $F$. arcus, $F$. vaucheriae, $F$. cf. exiguiformis, S. robusta (a), S. parasitoides, $S$. microstriata, F. nanana, $S$. cf. microstriata (b), $S$. microstriata (a).

D) Taxa responding to DOC (log. range from $0.4-2.1$ $\mathrm{mg}^{-1}$; in increasing order) were: $S$. microstriata (a), $S$. pseudoconstruens, $F$. rumpens, $F$. danica, $F$. vaucheriae, $F$. capucina.

In addition to the four main environmental variables, $F$. gracilis/nanoides and $F$. delicatissima responded to 
increasing relative water depth $\left(Z_{\text {rel }}\right)$. Along the environmental gradient of maximum water depth $\left(Z_{\max }\right)$, Fragilaria spec. 1 occurred in the deepest lakes, followed by taxa of the $F$. capucina complex, $F$. danica, and $F$. arcus at decreasing water depths. Most of the Staurosira taxa (benthic) occurred in shallow waters, with the exception of $S$. microstriata that was present when water depth increase (Figs 6 and 7).

\subsection{Relationship valve length/water temperature}

The distribution of the mean valve lengths of three selected taxa versus mean summer water temperatures (July, August) is illustrated in figure 9. Despite the errors associated with estimating the mean valve lengths, all three species show a minimum valve length within the temperature range of the lakes where the species occur. Fragilaria delicatissima and $F$. nanoides showed a minimum in valve length between 10 and $11{ }^{\circ} \mathrm{C}$ mean August water temperature (Fig. 9A). In F. cf. exiguiformis the size minimum corresponds with the mean July water temperature optimum of this taxon at $9.4^{\circ} \mathrm{C}$ as estimated from the transfer function (see arrow in Fig. 9B).

\section{DISCUSSION}

The PCA indicates correlations between the main environmental variables $\mathrm{pH}, \mathrm{T}_{\text {July }}$, length of ice cover, DOC and water depth. The length of ice cover and $\mathrm{T}_{\text {July }}$ show, however, unique effects on the diatom assemblages. The main difference between the total diatom data set and the Fragilariaceae subset is the minor importance of DOC and nutrients for the latter.

\section{1. pH/alkalinity response}

The CCA results (Tab. 3B) and the high number of significant responses (Fig. 8) support the strong impact of $\mathrm{pH} /$ alkalinity on diatom distribution in Alpine lakes (Marchetto \& Schmidt 1993; Koinig et al. 1998; Cameron et al. 1999). Bedrock mineralogy strongly determines the chemistry (e.g. by $\mathrm{Ca}^{2+}$ availability) of the Niedere Tauern lakes (Kamenik et al. 2001). Staurosira pinnata s. 1. prevailed in shallow waters with an increased $\mathrm{pH}$ that occurred in lakes on carbonate-bearing bedrock. This result conforms to observations from Lotter \& Bigler (2000) who observed high abundances of Fragilaria pinnata in the littoral and sublittoral of a Swiss Alpine lake on carbonate bedrock.

In the lakes of the Niedere Tauern $S$. aff. venter (1) was associated with $S$. pinnata s. 1. Similar ecological preferences suggest that the three morphotypes of $S$. aff. venter (1a-c) belong to one and the same taxon. The bootstrapped $\mathrm{pH}$ optimum of the morphotype (2) of $F$. aff. venter indicate, however, a lower $\mathrm{pH}$ optimum than for type (1) supporting the differentiation from type (1). This finding supports the meaning that $F$. construens var. venter auct. resembles taxa with different ecological preferences (see Rumrich et al. 2000).
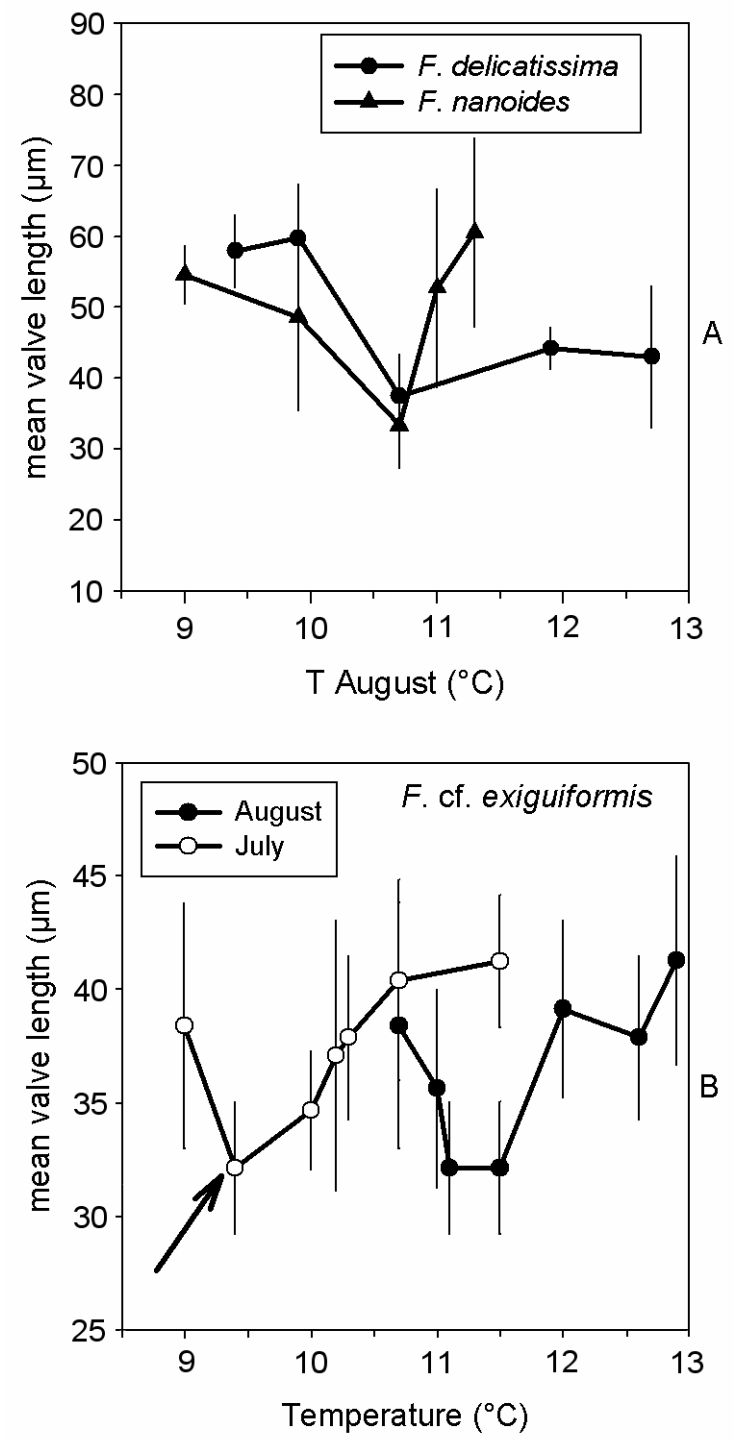

Fig. 9. Mean valve length $(\mathrm{n}=50$, standard deviation is indicated) of (A) two selected planktonic taxa versus mean August water temperature, and (B) $F$. cf. exiguiformis versus mean July and August water temperatures. The bootstrapped mean July water temperature of this species in the Niedere Tauern training set (see Fig. 8) is arrowed. Note the correspondent minimum mean valve length.

Similar to $S$. pinnata s. 1., S. robusta belongs to this group that is primarily ordinated by $\mathrm{pH}$. The morphotype (b) has, however, a higher $\mathrm{pH}$ optimum than morphotype (a).

With the lowering of the $\mathrm{pH}, S$. microstriata and $S$. cf. microstriata, which belong to the Fragilaria brevistriata complex, became abundant. From the benthic taxa $F$. cf. exiguiformis had the lowest $\mathrm{pH}$ optimum (Fig. 8). The larger-sized taxon $F$. cf. exiguiformis of the Niedere Tauern occurred, however, at the upper limit of the $\mathrm{pH}$ range which was mentioned by Flower et al. (1996) for European populations of $F$. exiguiformis. The sigmoidal species response to $\mathrm{pH}$ (see HOF report in Fig. 8) indi- 
cating a truncated curve, as was illustrated by Flower et al. (1996) for Antarctic populations of $F$. exiguiformis. The truncated curve may also explain the larger valve size of the Niedere Tauern population when we hypothesize that minimum valve length corresponds with the species $\mathrm{pH}$ optimum (see chapter 4 ).

\subsection{Duration of ice cover, mean July water temperature, and lake water depths}

Staurosira pinnata var. intercedens at higher $\mathrm{pH}$, and $F$. cf. exiguiformis at a lower $\mathrm{pH}$ characterize littoral benthic diatom assemblages in warmer waters. Both differ by their higher $\mathrm{T}_{\text {July }}$ optimum from $S$. microstriata that characterize deeper cold waters with prolonged ice cover. This finding corresponds with the temperature inference of "F. exigua" and "F. brevistriata" in Swedish lakes by Bigler et al. (2000). As a result of the taxonomic uncertainty in the $F$. brevistriata complex, comparisons with other areas are limited at the present stage. $S$. microstriata was common in the sediments of the Alpine lake Hobschensee, Swiss Alps, as well as in lateglacial sediments of the Tatra Mountains (Marciniak 1986, 1988). Taxa comparable with S. microstriata and $S$. cf. microstriata were illustrated by Lange-Bertalot \& Metzeltin (1996) for Julma Ölkky, an oligotrophic lake in Finland. These findings suggest that both might be widespread in alpine and arctic/subarctic environments. The similar ecological preferences in the Niedere Tauern data set suggest that both belong to the same species. The ecological preferences of $S$. parasitoides, which also belongs to the $F$. brevistriata complex, for shallow habitats that become warmer during the summer in lakes with an increased $\mathrm{pH}$ supports the splitting from the closely related $S$. microstriata (Schmidt et al. 2004). Geographical distribution and ecology separate this group of taxa from others of the $F$. brevistriata complex that occur in alkaline, high conductivity, lakes e.g. in coastal lakes (Wunsam et al. 1999).

Fragilaria capucina, F. amphicephala, F. arcus, and $F$. vaucheriae occurred in the lakes of the Niedere Tauern with a longer growing season and increased summer water temperatures. They might belong, however, to different habitats at increasing water depths (see Fig. 7); probably more elaborate benthic, or even tychoplanktonic taxa (switching between benthic and planktonic life forms) accompany attached ones (e.g. F. vaucheriae). Their occurrences at an increased summer temperature conform to their distribution in lakes below the subarctic treeline (Stevenson et al. 1996; Laing \& Smol 2000). The early formation of an ice-free "moat" (Smol 1988; Smol \& Cumming 2000), which provides marginal open waters in a still ice covered lake, might favor this diatom group. It is possible that minor scaling exists. In lakes with a lower $\mathrm{pH}, F$. rumpens at the expense of the former group might increase in abundance when the length of ice cover increases (vice versa $\mathrm{T}_{\text {July }}$ decrease).
The duration of ice cover (vice versa the length of the growing season) affects the abundance of planktonic taxa in Alpine (Lotter \& Bigler 2000) and subarctic to high Arctic lakes (Douglas et al. 1994; Pienitz et al. 1995; Adrian et al. 1999; Laing \& Smol 2000). Our data set indicated that the duration of ice cover and July summer water temperatures are closely related with each other, and affect species distribution. F. danica and $F$. spec. 1 occurred in warmer lakes with an increased growing season when compared with the planktonic groups as mentioned above. Within these planktonic taxa, $F$. nanana tolerates a longer ice cover. In lakes with open waters less than 2 month, no planktonic Fragilaria taxa were present. Hence, most of the lakes without planktonic Fragilaria occur above the alpine treeline. These findings compare with observations from planktonic taxa in circum-subarctic treeline lakes (Pienitz et al. 1995; Weckström et al. 1997a, b; Rosén et al., 2000; Bigler et al. 2000; Laing \& Smol 2000).

The significance of lake size and water depth which explains the planktonic diatom variation in the Niedere Tauern data set conforms to the hypotheses which relate occurrences of planktonic taxa to increasing water depth and water volume (see Wolin \& Duthie 1999). The commonly high light penetration extends the euphotic zone in alpine lakes, favoring planktonic diatoms. The planktonic needle-like elongated taxa $F$. delicatissima, $F$. nanoides, $F$. spec 1 , and $F$. nanana characterize these larger and deeper lakes. At least the elongated valves of $F$. gracilis might also belong to this group. Only the planktonic $F$. danica occurred in smaller, shallower lakes.

\subsection{DOC and nutrient response}

Taxa of the Fragilaria capucina complex ( $F$. capucina, $F$. vaucheriae, $F$. rumpens) and $F$. danica that occurred at highest DOC increase in abundance in lakes below the alpine treeline. This diatom distribution follows the general trend of DOC increase from high alpine lakes towards lakes located at the forested belts (Sommaruga-Wögrath et al. 1999). In contrast to the former group, S. microstriata and S. pseudoconstruens characterize highly oligotrophic cold water lakes with low DOC. The lower altitude lakes are commonly more affected by human impact than the remote lakes at higher altitudes. DOC is associated with dissolved phosphorus. Probably due to the low concentrations, dissolved phosphorus and nitrogen showed, however, no significant $\left(\mathrm{P}_{\mathrm{adj}}<0.05\right)$ impact on the distribution of the Fragilaria and Staurosira taxa in the Niedere Tauern lakes. The occurrences of Fragilaria Spec. 1 in the mountain lakes question the conspecifity of this taxon with "F. acus var. angustissima" (see the chapter taxonomy) which commonly is mentioned from meso- to eutrophic low altitude lakes, or there exists a mountain strain which is adapted to oligo- to ultra-oligotrophic conditions. 


\subsection{Valve size variation}

According to Atkinson (1994, 1996), variations in size between organisms can be produced by genetic adaptation to temperature and by environmentally induction among individuals of a given genotype. Small-sized taxa of Fragilariaceae frequently occur in high altitude and latitude lakes. Prolonged ice cover (Smol 1988) and low temperatures (Pienitz et al. 1995; Weckström et al. 1997a, b; Bigler et al. 2000; Laing \& Smol 2000; Rosén et al. 2000) have been cited as a possible factor explaining high abundances of small Fragilariaceae in these areas. In our data set also taxa on intra-specific level follow this trend. The larger-sized $S$. pinnata var. intercedens occurred at higher $\mathrm{T}_{\text {July }}$ than the small $S$. pinnata var. subrotundata. The same is true for the larger $S$. robusta (b) (forma "bigibba") that showed a higher temperature optimum than morphotype (a). In both cases, the larger-sized taxa also have a higher $\mathrm{pH}$ optimum. The finding of the $\mathrm{pH} /$ temperature coupling fits to diatom-inferred $\mathrm{pH}$ and correspondent temperature curves which were recognized in Alpine lake sediment cores (Psenner \& Schmidt 1992; Koinig et al. 1998).

Montagnes \& Franklin (2001) postulated, based on temperature/size experiments on cultured diatom clones, and on the literature, that the size of diatoms decrease with increasing temperature, and thus diatoms follow the rule of Atkinson (1994) of temperature-dependent organism size. In the Niedere Tauern data set the minimum mean valve length in $F$. cf. exiguiformis approximates the bootstrapped temperature optimum of this taxon. This finding was explained that the temperature optimum (i) stimulates enhanced cell division, or (ii) cells did not reproduce sexually. Cell division was observed to accelerate with increasing temperature (Lloyd et al. 1982). Probably, July water temperature is accompanied by other environmental variables all together stimulating growth and cell division of algae in mountain lakes during summer season; e.g. higher light intensities and duration stimulating photosynthesis, or enhanced nutrient availability after snow and ice-melt (Sommaruga-Wögrath et al. 1999).

\section{CONCLUSIONS}

- The $\mathrm{pH} /$ alkalinity, mean July water temperature $\left(\mathrm{T}_{\text {July }}\right)$, duration of ice cover, and DOC were the main environmental variables significantly $\left(\mathrm{P}_{\mathrm{adj}}\right.$ $<0.05)$ explaining Fragilaria and Staurosira distribution in the 40 mountain lakes of the Niedere Tauern (Austria). At the third CA axis, water depths made an additional significant contribution to explain their distribution.

- The $\mathrm{pH}$ and the related variable alkalinity depend on catchment geology (crystalline vs carbonate-bearing schists and metamorphic carbonates), and both are related to $\mathrm{T}_{\text {July }}$.
- The comparison between the total diatom training set and the Fragilariaceae subset stressed the high sensitivity of Fragilaria and Staurosira to the climate-driven variables "duration of ice cover" and "mean July water temperature". DOC showed a lower impact in the Fragilariaceae subset than in the total diatom data set.

- The Staurosira pinnata, S. aff. venter (1), and S. robusta complexes are frequent benthic taxa in the littoral and sublittoral of lakes with higher $\mathrm{pH}$, whereas at a lower $\mathrm{pH} F$. cf. exiguiformis predominates. This taxon differs by a higher summer temperature optimum from the $F$. brevistriata complex (S. microstriata) that characterizes deeper cold water lakes with prolonged ice cover.

- The planktonic and possible tychoplanktonic Fragilaria taxa occurred at higher $\mathrm{T}_{\text {July }}$ (and vice versa shorter duration of ice cover) and DOC ( $F$. danica, $F$. spec. 1, and $F$. capucina complex), and increasing lake water depth and size (needle-like planktonic taxa).

- Differences or similarities along environmental gradients suggested the splitting (e.g. S. parasitoides from $S$. microstriata, $S$. aff. venter (1) from (2)), or lumping of taxa (e.g. $S$. aff. venter morphotypes (1ac)).

- Valve length appeared to be affected by temperature in two different ways; (i) Generally, smaller-sized taxa on species and intra-specific levels (e.g. S. brevistriata and S. pinnata s. 1.) indicate (genetic) adaptation to cold waters (low temperature optimum); (ii) Stimulation of enhanced cell divison and supression of sexual reproduction at the species temperature optimum are thought to be responsible for the minimum mean valve length within populations.

- The high importance of the climate-driven environmental variables for species distribution and reproduction affecting valve size underline the high potential of Fragilaria and Staurosira for palaeoclimatic reconstructions in mountain lakes.

\section{ACKNOWLEDGMENTS}

We would like to thank B. Franzoi and W. Müller for chemical analyses; G. Kum for lake surface area measurements; P. Indinger and numerous volunteers for help in the field; J. Knoll for technical help and M.H. Lyman for proofreading. We would also like to thank S. Spaulding for helpful critical comments made on the manuscript. This study was part of the project P14912B06 funded by the Austrian Science Fund (FWF Project P14912-B06).

\section{REFERENCES}

Adrian, R., N. Walz, T. Hintze, S. Hoeg \& R. Rusche. 1999. Effects of ice duration on plankton succession during spring in a shallow polymictic lake. Freshwat. Biol., 41: 621-632. 
Atkinson, D. 1994. Temperature and organism size - a biological law for ecotherms? Adv. Ecol. Res., 25: 1-54.

Atkinson, D. 1996. Ecotherm life-history responses to developmental temperature. In: Johnson, I.A. \& A.F. Bennett (Eds), Animals and Temperature. Phenotypic and Evolutionary Adaptation. Seminar Series 59. Cambridge University Press: 419 pp.

Battarbee, R.W. 1986. Diatom Analysis. In Berglund, B.G. (Ed.), Handbook of Holocene Palaeoecology and Palaeohydrology. John Wiley \& Sons, London: 527-570 pp.

Birks, H.J.B. 1995: Quantitative palaeoenvironmental reconstructions. In: Maddy, D. \& J.S. Brews (Eds), Statistical Modelling of Quaternary Science Data. Quaternary Research Association, Cambridge, Technical Guide 5: 161$254 \mathrm{pp}$.

Bigler, C., R. Hall \& I. Renberg. 2000. A diatom training set for paleoclimatic inferences from lakes in Northern Sweden. Verh. int. Ver. Limnol., 27: 1174-1182.

Borcard, D., P. Legende \& P. Drapeau. 1992. Partialling out the spatial component of ecological variation. Ecology, 73 1045-1055.

Cameron, N.G., H.J.B. Birks, V.J. Jones, F. Berge, J. Catalan, R.J. Flower, J. Garcia, B. Kaecka, K.A. Koinig, A. Marchetto, P. Sanchez-Castillo, R. Schmidt, M. Sisko, N. Solovieva, E. Stefkova \& M. Toro Valasquez. 1999. Surface-sediment and epilithic diatom $\mathrm{pH}$ calibration sets for remote European mountain lakes (AL:PE Project) and their comparison with the Surface Water Acidification Programme (SWAP) calibration sets. J. Paleolimnol., 22: 291-319.

Catalan, J., M. Ventura, A. Brancelj, I. Granados, H. Thies, U. Nickus, A. Korhola, A.F. Lotter, A. Barbieri, E. Stuchlík, L. Lien, P. Bitušik, T. Buchaca, L. Camarero, G.H. Goudsmit, J. Kopáćek, G. Lemcke, D.M. Livingstone, B. Müller, M. Rautio, M. Šiško, S. Sorvari, F. Sporka, O. Strunecký \& M. Toro. 2002. Seasonal ecosystem variability in remote mountain lakes: implications for detecting climatic signals in sediment records. J. Paleolimnol., 28: 25-46.

Douglas, M.S.V., J.P. Smol \& W. Blake. 1994. Marked post$18^{\text {th }}$ century environmental change in High-Arctic ecosystems. Science, 266: 416-419.

Douglas, M.S.V. \& J.P. Smol. 1995. Periphytic diatom assemblages from high Arctic ponds. J. Phycol., 31: 60-69.

Flower, R.J., V.J. Jones \& F.E. Round. 1996. The distribution and classification of the problematic Fragilaria (virescens V.) exigua Grun./Fragilaria exiguiformis (Grun.) LangeBertalot: A new species or a new genus? Diatom Res., 11(1): 41-57.

Foged, N. 1974. Freshwater Diatoms in Iceland. Bibliotheca Phycologica, 15: 1-118.

Hamilton, P.B., M. Poulin, D.F. Charles \& M. Angell. 1992. Americanarum Diatomarum Exsiccata: CANA, Voucher slides from eight acidic lakes in the northeastern North America. Diatom Res., 7: 25-36.

Haworth, E.Y., 1975: A scanning electron microscope study of some different frustule forms of the genus Fragilaria found in Scottish late-glacial sediments. Br. Phycol. J., 10: 73-80.

Haworth, E.Y. 1976. Two late-glacial (Late-Devensian) diatom assemblage profiles from northern Scotland. New Phytol., 77: 227-256.

Hochberg, Y. 1988. A sharper Bonferroni procedure for multiple tests of significance. Biometrika, 75: 800-802.

Huisman, J., H. Olff \& L.F.M. Fresco. 1993. A hierarchical set of models for species response analysis. J. Veg. Sci., 4: 3746.

Hustedt, F. 1943. Die Diatomeenflora einiger Hochgebirgsseen der Landschaft um Davos in den Schweizer Alpen. Arch. Hydrobiol., 43: 124-197.
Jackson, O. 1993. Stopping rules in principal component analysis: a comparison of heuristical and statistical approaches. Ecology, 74: 2204-2214.

Juggins, S. 2003. C2 User guide. Software for ecological and palaeoecological data analysis and visualisation. University of Newcastle, Newcastle upon Tyne, UK: 69 pp.

Kamenik, C., R. Schmidt, G. Kum \& R. Psenner. 2001. The Influence of Catchment Characteristics on the Water Chemistry of Mountain Lakes. Arctic Antarctic Alpine Res., 33(4): 404-409.

Koinig, K.A., R. Schmidt, S. Sommaruga-Wögrath, R.Tessadri \& R. Psenner. 1998. Climate change as the primary cause of $\mathrm{pH}$ shifts in a high alpine lake. Water Air Soil Pollut., 104: 167-180.

Krammer, K. \& H. Lange-Bertalot. 1991. Süßwasserflora von Mitteleuropa, Bacillariophyceae. 3. Teil: Centrales, Fragilariaceae, Eunotiaceae. Ettl, H., J. Gerloff, H. Heynig \& D. Mollenhauer, 2/3, G. Fischer Verlag, Jena, Stuttgart: $576 \mathrm{pp}$

Krammer, K. \& H. Lange-Bertalot. 2000. Süßwasserflora von Mitteleuropa, Bacillariophyceae, Second emended edition 2/3 Teil. Spectrum Akademischer Verlag, Heidelberg, Berlin: 599 pp.

Laing, T.E. \& J.P. Smol. 2000. Factors influencing diatom distributions in circumpolar treeline lakes of northern Russia. J. Phycol., 36: 1035-1048.

Laing, T.E., R. Pienitz \& J.P. Smol. 1999. Freshwater diatom assemblages from 23 lakes located near Norilsk, Siberia: a comparison with assemblages from other circumpolar treeline regions. Diatom Res., 14(2): 285-305.

Lange-Bertalot, H. 1980. Zur systematischen Bewertung der bandförmigen Kolonien bei Navicula und Fragilaria. Kriterien für die Vereinigung von Synedra (subgen. Synedra) Ehrenberg mit Fragilaria Lyngbye. Nova Hedwigia, 33: 723-787.

Lange-Bertalot, H. \& D. Metzeltin. 1996. Indicators of oligotrophy. 800 taxa representative of three ecologically distinct lakes. Carbonate buffered - oligodystrophic weakly buffered soft water. Iconographia Diatomologica, 2: $390 \mathrm{pp}$

Lange-Bertalot, H. \& P. Compère. 2001. Fragilaria subgen. Ulnaria comb. nov., the correct name of the subgenus including Synedra ulna, when treated in Fragilaria. Diatom Res., 16(1): 103-104.

Lloyd, D., R.K. Poole \& S.W. Edwards. 1982. The Cell Division Cycle. Academic Press London.

Lotter, A.F., R. Pienitz \& R. Schmidt. 1999. Diatoms as indicators of environmental change near Arctic and Alpine treeline. In Stoermer, E.F. \& J.P. Smol (Eds), The diatoms: application for the environmental and earth sciences. Cambridge University press, Cambridge: 205-226.

Lotter, A.F. C. \& C. Bigler. 2000. Do diatoms in the Swiss Alps reflect the length of ice-cover? Aquat.Sci., 62: 125141 .

Marchetto, A. \& R. Schmidt. 1993. A regional calibration data set to infer lake water $\mathrm{pH}$ from sediment diatom assemblages in alpine lakes. Mem. Ist. ital. Idrobiol., 51: 115125 .

Marciniak, B. 1986. Late Quaternary diatoms in the sediments of Przedni Staw Lake (Polish Tatra Mountains). Hydrobiologia, 143: 255-265.

Marciniak, B. 1988. Late Glacial Fragilaria flora from lake sediments of the Tatra Mts. and the Alps. In: Round, F.E. (Ed.) Proceedings of the $9^{\text {th }}$ Diatom-Symposium 1986, Biopress Ltd., Bristol and Koeltz, Königstein: 233-241.

Montagnes, D.J.S. \& D.J. Franklin. 2001. Effect of temperature on diatom volume, growth rate, and carbon and nitrogen content: Reconsidering some paradigms. Limnol. Oceanogr., 46: 2008-2018.

Pienitz, R., J.P. Smol\& H.J.B. Birks.1995: Assessment of freshwater diatoms as quantitative indicators of past cli- 
mate change in the Yukon and Northwest Territories, Canada. J. Paleolimnol., 13: 21-49.

Psenner, R. \& R. Schmidt, R. 1992. Climate-driven pH control of remote alpine lakes and effects of acid deposition. Nature, 365: 781-783.

Rosén, P., R. Hall, T. Korsman \& I. Renberg, I. 2000. Diatom transfer-functions for quantifying past air temperature, $\mathrm{pH}$ and total organic carbon concentrations from lakes in northern Sweden. J. Paleolimnol., 24: 109-123.

Rumrich, U., H. Lange-Bertalot M. Rumrich. 2000. Diatoms of the Andes from Venezuela to Patagonia/Tierra del Fuego. Iconographia Diatomologica, 9: 1-649.

Schmidt, R., K.A. Koinig, R. Thompson \& C. Kamenik. 2002. A multi proxy core study of the last 7000 years of climate and alpine land-use impacts on an Austrian mountain lake (Unterer Landschitzsee, Niedere Tauern). Palaeogeography, Palaeoclimatology, Palaeoecology, 187: 101-120.

Schmidt, R., H. Lange-Bertalot \& R. Klee. 2004. Staurosira parasitoides nov. spec. and Staurosira microstriata (Marciniak) Lange-Bertalot from surface sediment samples of Austrian alpine lakes. Algological Studies: (in press).

Smol, J.P. 1988. Paleoclimate proxy data from freshwater arctic diatoms. Verh. int. Ver. Limnol., 23: 837-844.

Smol, J.P. \& B. Cumming. 2000. Tracking long-term changes in climate using algal indicators in lake sediments. J. Phycol., 36: 986-1011.

Sommaruga-Wögrath, S., R. Psenner, E. Schafferer, K.A. Koinig \& S. Sommaruga-Wögrath. 1999. Dissolved organic carbon concentration and phytoplankton biomass in high-mountain lakes of the Austrian Alps: Potential effects of climate warming on UV underwater attenuation. Arctic Antarctic Alpine Res., 31: 247-253.

Stevenson, R.J., M.L. Bothwell R.L. Lowe (Eds) 1996. Algal Ecology: Freshwater Benthic Ecosystems. Academic Press, San Diego, 753 pp.

Received: March 2004

Accepted: May 2004 ter Braak, C.J.F. 1987. The analysis of vegetation-environment relationships by canonical correspondence analysis. Vegetatio, 69: 69-77.

ter Braak, C.J.F. \& P. Šmilauer, P., 2002. CANOCO Reference Manual and CanoDraw for Windows User's Guide: Software for Canonical Community Ordination (version 4.5). Biometrics. Wageningen and Česke Budějovice: 500 pp.

Weckström, J., A. Korhola \& T. Blom. 1997a. Diatoms as quantitative indicators of $\mathrm{pH}$ and water temperature in subarctic Fennoscandian lakes. Hydrobiologia, 347: 171184.

Weckström, J., A. Korhola \& T. Blom. 1997b: The relationship between diatoms and water temperature in thirty subarctic Fennoscandian lakes. Arctic Antarctic Alpine Res., 29: 75-92

Williams, D.M. \& F. Round. 1986. Revision of the genus Synedra Ehrenb. Diatom Res., 1: 313-339.

Williams, D.M. \& F.E. Round. 1987: Revision of the genus Fragilaria. Diatom Res., 2(2): 267-288.

Witkonski, A. 1994. Recent and fossil diatom flora of the Gulf of Gedansk, Southern Baltic Sea. Bibl. Diotomol., 28: 1-313.

Wögrath, S. \& R. Psenner. 1995. Seasonal, annual and longterm variability in the water chemistry of a remote high mountain lake: acid rain versus natural changes. Water Air Soil Pollut., 85: 359-364.

Wolin, J.A. \& H.C. Duthie. 1999. Diatoms as indicators of water level change in freshwater lakes. In: Stoermer, E.F. and Smol, J.P (Eds), The Diatoms: Applications to the Environmental and Earth Sciences. Cambridge University Press, Cambridge: 183-202.

Wunsam, S., R. Schmidt \& J. Müller. 1999. Holocene lake development of two Dalmatian lagoons (Malo and Veliko Jezero, Isle of Mljet) in respect to changes in Adriatic sealevel and climate. Palaeogeography Palaeoclimatology Palaeoecology, 146: 251-281. 